Published in final edited form as:

ACS Chem Neurosci. 2018 September 19; 9(9): 2274-2285. doi:10.1021/acschemneuro.8b00131.

\title{
A Novel $M_{1}$ PAM VU0486846 Exerts Efficacy in Cognition Models without Displaying Agonist Activity or Cholinergic Toxicity
}

\author{
Jerri M. Rook ${ }^{\dagger, \|}$, Jeanette L. Bertron ${ }^{\ddagger}$, Hyekyung P. Cho ${ }^{\dagger}, \|$, Pedro M. Garcia-Barrantes $\|$, \\ Sean P. Moran ${ }^{\dagger}, \|$, James T. Maksymetz ${ }^{\dagger, \|}$, Kellie D. Nance ${ }^{\dagger, \|}$, Jonathan W. Dickerson $^{\dagger}, \|$, \\ Daniel H. Remke ${ }^{\dagger, \|}$, Sichen Chang", Joel M. Harp ${ }^{\S}$, Anna L. Blobaum ${ }^{\dagger}, \|$, Colleen M. \\ Niswender ${ }^{\dagger, \|, \perp}$, Carrie K. Jones ${ }^{\dagger, \|}$, Shaun R. Stauffer ${ }^{\dagger}$, P. Jeffrey Conn ${ }^{\dagger, \|, \perp}$, and Craig W. \\ Lindsley $\dagger, \ddagger, \S, \|,{ }^{*}$ \\ †Department of Pharmacology, Vanderbilt University, Nashville, Tennessee 37232-6600, United \\ States \\ ‡Department of Chemistry, Vanderbilt University, Nashville, Tennessee 37232-6600, United States \\ $\S$ Department of Biochemistry, Vanderbilt University, Nashville, Tennessee 37232-6600, United \\ States \\ "Vanderbilt Center for Neuroscience Drug Discovery, Vanderbilt University, Nashville, Tennessee \\ 37232-6600, United States \\ ${ }^{\perp}$ Vanderbilt Kennedy Center, Vanderbilt University, Nashville, Tennessee 37232-6600, United \\ States
}

\begin{abstract}
Selective activation of the $\mathrm{M}_{1}$ subtype of muscarinic acetylcholine receptor, via positive allosteric modulation (PAM), is an exciting strategy to improve cognition in schizophrenia and Alzheimer's
\end{abstract}

\footnotetext{
"Corresponding Author: Address: Departments of Pharmacology and Chemistry, Vanderbilt Center for Neuroscience Drug Discovery, Vanderbilt University School of Medicine, Nashville, TN 37232-6600, USA. craig.lindsley@ vanderbilt.edu. Phone: 615-322-8700. Fax: 615-343-6532. 
disease patients. However, highly potent $\mathrm{M}_{1}$ ago-PAMs, such as MK-7622, PF-06764427, and $\mathrm{PF}-06827443$, can engender excessive activation of $\mathrm{M}_{1}$, leading to agonist actions in the prefrontal cortex (PFC) that impair cognitive function, induce behavioral convulsions, and result in other classic cholinergic adverse events (AEs). Here, we report a fundamentally new and highly selective $\mathrm{M}_{1}$ PAM, VU0486846. VU0486846 possesses only weak agonist activity in $\mathrm{M}_{1^{-}}$ expressing cell lines with high receptor reserve and is devoid of agonist actions in the PFC, unlike previously reported ago-PAMs MK-7622, PF-06764427, and PF-06827443. Moreover, VU0486846 shows no interaction with antagonist binding at the orthosteric acetylcholine (ACh) site (e.g., neither bitopic nor displaying negative cooperativity with $\left[{ }^{3} \mathrm{H}\right]-\mathrm{NMS}$ binding at the orthosteric site), no seizure liability at high brain exposures, and no cholinergic AEs. However, as opposed to ago-PAMs, VU0486846 produces robust efficacy in the novel object recognition model of cognitive function. Importantly, we show for the first time that an $\mathrm{M}_{1}$ PAM can reverse the cognitive deficits induced by atypical antipsychotics, such as risperidone. These findings further strengthen the argument that compounds with modest in vitro $\mathrm{M}_{1} \mathrm{PAM}$ activity $\left(\mathrm{EC}_{50}>100 \mathrm{nM}\right)$ and pure-PAM activity in native tissues display robust procognitive efficacy without AEs mediated by excessive activation of $\mathrm{M}_{1}$. Overall, the combination of compound assessment with recombinant in vitro assays (mindful of receptor reserve), native tissue systems (PFC), and phenotypic screens (behavioral convulsions) is essential to fully understand and evaluate lead compounds and enhance success in clinical development.

\section{Graphical Abstract}
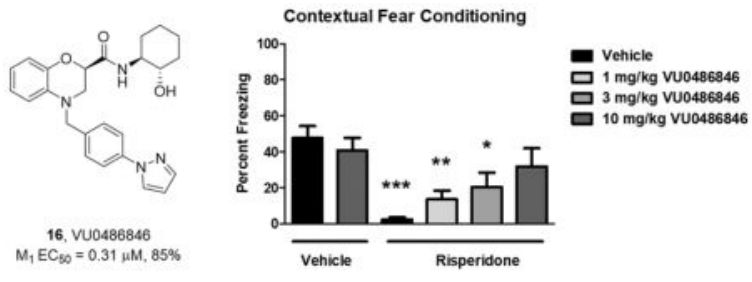

\section{Keywords}

$\mathrm{M}_{1}$; muscarinic acetylcholine receptor; agonist; positive allosteric modulator; ago-PAM; cognition; schizophrenia

\section{INTRODUCTION}

Of the five muscarinic acetylcholine receptor subtypes $\left(\mathrm{M}_{1}-\mathrm{M}_{5}\right)$, extensive biochemical, genetic, and patient data have implicated selective activation of $\mathrm{M}_{1}$ as an attractive approach for the treatment of the cognitive deficits associated with both schizophrenia and Alzheimer's disease (AD). ${ }^{1-15}$ Early efforts to selectively activate $\mathrm{M}_{1}$ with pan-muscarinic agonists ultimately failed due to a lack of subtype selectivity, resulting in severe gastrointestinal (GI) disturbances and SLUD (salivation, lacrimation, urination, defecation) due to activation of peripheral $\mathrm{M}_{2}$ and $\mathrm{M}_{3} \cdot{ }^{16}$ However, Phase II and Phase III clinical trials with these agonists demonstrated procognitive efficacy. ${ }^{17,18}$ Thus, the field moved to targeting less conserved allosteric binding sites on the $\mathrm{M}_{1}$ receptor and achieved unprecedented levels of muscarinic subtype selectivity with positive allosteric modulators 
(PAMs). ${ }^{1,2,12-14}$ BQCA was the first of these compounds disclosed (Figure 1). ${ }^{19-21}$ However, BQCA and related analogues, such as the subsequent clinical compound MK-7622, ${ }^{22}$ are robust ago-PAMs demonstrating direct agonist activity in addition to PAM activity in both in vitro recombinant systems and native tissues. ${ }^{19-23}$ In addition, they appear to interact with the orthosteric site, which may contribute to their severe seizure liability and other cholinergic adverse effects (AEs), as well as limit their procognitive efficacy. ${ }^{19-23}$ An early compound derived from our internal high-throughput screening (HTS) campaign, ${ }^{24}$ VU0453595 (VU595), proved to be a pure-PAM, devoid of direct agonist activity, in both recombinant and native systems. Additionally, VU595 was devoid of AEs and possessed procognitive activity. However, VU0453595 is a weak $\mathrm{M}_{1}$ PAM with a potency at $\mathrm{M}_{1}$ in the low micromolar range. ${ }^{25}$ Derived from another HTS hit, VU6004256 is a more potent $\mathrm{M}_{1}$ PAM, with agonist activity in high receptor reserve recombinant cell lines, yet is devoid of behavioral convulsions and cholinergic AEs in rodents. ${ }^{26,27}$ Unlike the structurally related $\mathrm{M}_{1}$ ago-PAM PF-06764427 ${ }^{28}$ and the reported $\mathrm{M}_{1}$ PAM PF-06767832, ${ }^{29}$ VU6004256 displays procognitive efficacy in rodents. ${ }^{26,27}$ Furthermore, despite very low agonist activity in a recombinant in vitro cell line, PF-06827443 still elicited robust cholinergic AEs across species and induced seizures in mice. ${ }^{29}$ Recently, we demonstrated that similar to MK-7622, ${ }^{22} \mathrm{PF}-06827443$ is a potent agonist in native systems (prefrontal cortex (PFC)), and that agonist activity in native tissues accurately predicts the magnitude of in vivo efficacy/toxicity. ${ }^{30}$ Thus, the field does not have a robust in vivo $\mathrm{M}_{1}$ PAM with the ideal properties to critically evaluate the role of $\mathrm{M}_{1}$ in $\mathrm{CNS}$ biology. Therefore, we are reporting VU0486846, a highly selective, potent $\mathrm{M}_{1}$ PAM devoid of agonist activity in native tissues and cholinergic AEs, with robust procognitive efficacy, for the benefit of the research community to study selective $\mathrm{M}_{1}$ activation in vitro and in vivo.

\section{RESULTS AND DISCUSSION}

\section{Ligand Design toward the Next Generation of $M_{1}$ PAMs}

Having exhausted our indole-based series of $M_{1}$ PAMs (e.g., VU6004256), ${ }^{26,27}$ we revisited where the $\mathrm{M}_{1}$ PAM field began-with BQCA. ${ }^{19-22}$ The discovery of the $(1 S, 2 S)$-2aminocyclohexan-1-ol amide moiety, as replacement for the carboxylic acid functionality of BQCA, as in 7, was a watershed event. ${ }^{31}$ Even more salient was the recognition that the secondary $\mathrm{N}-\mathrm{H}$ of $(1 S, 2 S)$-2-aminocyclohexan-1-ol amide moiety formed an intramolecular hydrogen bond (IMHB) with the carbonyl oxygen of the quinolone core. ${ }^{29-31}$ It was this recognition that led to the tricyclic core of MK-7622 and the azaindole core of PF-06764427. Utilizing the 6,6-fused ring system of BQCA and 7, we simultaneously increased $\mathrm{sp}_{3}$ character, while bringing the Lewis basic oxygen into the ring by scaffold hopping to a benzomorpholine core $\mathbf{8}$ (Figure 2). By virtue of this juxtaposition, we also created a new chiral center, and the opportunity for enantioselective $\mathrm{M}_{1}$ PAM activity while still maintaining the key intramolecular hydrogen bonding (IMHB) between the secondary amide $\mathrm{N}-\mathrm{H}$ and the benzomorpholine oxygen atom.

\section{Chemistry and Limited Structure-Activity Relationships (SAR)}

The chemistry to access benzomorpholine-based $\mathrm{M}_{1}$ PAMs was straightforward (Scheme 1). Following a standard route to the benzomorpholine core, commercial ethyl 2,3- 
dibromopropanoate 9 was condensed with 2-aminophenol to provide the key racemic heterocyclic core 10 in 65\% yield. Benzylation with 4-bromobenzyl bromide proceeded smoothly delivering 11, suitable for diversification, in $74 \%$ yield. A quantitative hydrolysis of the ester gave 12, which then underwent a HATU-mediated amide coupling with ( $1 S$, $2 S$ )-2-aminocyclohexan-1-ol to provide $\mathbf{1 3}$ as a mixture of diastereomers 13. Finally, a copper-mediated coupling with pyrazole produced the putative $\mathrm{M}_{1} \mathrm{PAM} \mathbf{1 4}$, in $65 \%$ yield.

Upon testing, 14 proved to be a human $\mathrm{M}_{1}$ PAM $\left(\mathrm{EC}_{50}=0.92 \mu \mathrm{M}, \mathrm{pEC}_{50}=6.1 \pm 0.13,77\right.$ $\pm 7 \%$ acetylcholine $(\mathrm{ACh}) \mathrm{Max})$ with weak $\mathrm{M}_{1}$ agonist activity $\left(\mathrm{EC}_{50}>10 \mu \mathrm{M}, 22 \% \mathrm{ACh}\right.$ Max). The diastereomers at the benzomorpholine chiral center were readily separable by column chromatography, affording isomer-1, 15 (VU0486834), and isomer-2, 16 (VU0486846). A single crystal X-ray structure determined the absolute stereochemistry of 16 (Figure 3 ) as the $(R)$-enantiomer and highlighted the IMHB. ${ }^{32}$ Moreover, enantioselective $\mathrm{M}_{1}$ PAM activity was noted, with $15\left(\mathrm{EC}_{50}=0.63 \mu \mathrm{M}, \mathrm{pEC}_{50}=6.21 \pm 0.0589 \pm 2 \% \mathrm{ACh}\right.$ Max and weak agonist activity $\mathrm{EC}_{50}>10 \mu \mathrm{M}, 16 \% \mathrm{ACh}$ Max) being less potent than VU0486846 $\left(\mathrm{EC}_{50}=0.31 \mu \mathrm{M}, \mathrm{pEC}_{50}=6.53 \pm 0.05,85 \pm 2 \%\right.$ ACh Max and weak agonist activity $\mathrm{EC}_{50}=4.0 \mu \mathrm{M}, \mathrm{pEC}_{50}=5.39 \pm 0.07,39 \pm 3 \% \mathrm{ACh}$ in our high expression line). These positive data necessitated a more in depth pharmacological evaluation of novel $\mathrm{M}_{1}$ PAM VU0486846, which also possessed a favorable central nervous system multiparameter optimization (CNS MPO) score (>5). ${ }^{33}$

\section{Molecular Pharmacology Studies and Adverse Effect Liability}

As shown previously, ${ }^{26,27}$ in our high expression human $\mathrm{M}_{1}$ cell line, VU0486846 was a moderately potent $\mathrm{M}_{1} \mathrm{PAM}\left(\mathrm{EC}_{50}=0.31 \mu \mathrm{M}, \mathrm{pEC}_{50}=6.53 \pm 0.05,85 \pm 2 \%\right.$ ACh Max $)$ with weak, partial agonist activity $\left(\mathrm{EC}_{50}=4.5 \mu \mathrm{M}, \mathrm{pEC}_{50}=5.37 \pm 0.07,29 \pm 6 \% \mathrm{ACh}\right)$. In our rat $\mathrm{M}_{1}$ cell line (also a high expression system), VU0486846 was an equipotent PAM $\left(\mathrm{EC}_{50}=0.25 \mu \mathrm{M}, \mathrm{pEC}_{50}=6.63 \pm 0.06,83 \pm 1 \%\right.$ ACh Max $)$ with weak, partial agonist activity $\left(\mathrm{EC}_{50}=5.6 \mu \mathrm{M}, \mathrm{pEC}_{50}=5.27 \pm 0.05,26 \pm 6 \% \mathrm{ACh}\right)$. In contrast, in our mouse $\mathrm{M}_{1}$ cell line with low expression, VU0486846 showed little agonism ( $9 \pm 1 \% \mathrm{ACh}$ Max), and good $\mathrm{M}_{1}$ PAM potency $\left(\mathrm{EC}_{50}=0.6 \mu \mathrm{M}, \mathrm{pEC}_{50}=6.25 \pm 0.10,77 \pm 4 \%\right.$ ACh Max $)$. Similarly, in our low expression $\mathrm{M}_{1}$ dog line, VU0486846 was a PAM $\left(\mathrm{EC}_{50}=0.38 \mu \mathrm{M}\right.$, $\mathrm{pEC}_{50}=6.41 \pm 0.03,78 \pm 1 \%$ ACh Max $)$ with minimal agonist activity $\left(\mathrm{EC}_{50}>10 \mu \mathrm{M}, 18\right.$ $\pm 0.2 \% \mathrm{ACh}$ Max). Agonism (full/partial) is a receptor reserve/expression-dependent driven pharmacology, whereas PAM activity is conserved across varying degrees of expression/ reserve, potentiating the $\mathrm{EC}_{20}$ orthosteric agonist effect. ${ }^{23}$ Therefore, the lower expression cell lines are more indicative of the native system. Demonstrating a lack of agonist activity in these in vitro systems or native tissues, such as the PFC, more accurately predicts a lack of CNS AEs. ${ }^{23,27,30}$ The lack of agonist activity in the lower expressing cell line by VU0486846, suggests that this compound will be devoid of seizure liability in vivo. A point worth mentioning is the potential for overstimulation of $\mathrm{M}_{1}$ with either a highly potent $\mathrm{M}_{1}$ PAM or a potent $\mathrm{M}_{1}$ ago-PAM exists, and would thereby lose the mechanistic advantage of potentiation by these allosteric modulators. As the in vitro cellular functional assays employ a subthreshold concentration of $\mathrm{ACh}$ (typically an $\mathrm{EC}_{20}$ concentration), in vivo PAM potency is arguably underestimated, as cholinergic tone in many brain regions may approach an $\mathrm{EC}_{100}$ levels and leftward shifts in PAM potency are observed with increasing ACh 
concentration. For example (Supporting Figure 1), ${ }^{32}$ with a very low level of ACh (an $\left.\sim \mathrm{EC}_{9}\right)$, VU0486846 exhibited an $\mathrm{M}_{1}$ PAM potency of $430 \pm 120 \mathrm{nM}(84 \pm 2 \%$ ACh Max $)$, but as ACh concentration was increased to an $\mathrm{EC}_{70}, \mathrm{M}_{1}$ PAM potency improved to $68 \pm 11$ $\mathrm{nM}(90 \pm 1 \%$ ACh Max $) .^{32}$ Similarly, PF-06827443 also showed an increase in $\mathrm{M}_{1}$ PAM potency from $40 \pm 6 \mathrm{nM}$ to $7 \pm 1 \mathrm{nM}$ at the same $\mathrm{ACh}$ concentration range. ${ }^{32}$ Thus, a very potent PAM or ago-PAM in vitro may lead to overactivation of $M_{1}$ in vivo leading to $M_{1^{-}}$ mediated seizure liability. After in vitro and in vivo evaluation of $\mathrm{M}_{1}$ PAMs across multiple chemotypes, $\mathrm{M}_{1}$ functional potencies in the $100-400 \mathrm{nM}$ potency range in vitro in our cellbased systems have proven to be a first step toward avoiding seizure liability in vivo. As shown in Figure 4, $\mathrm{M}_{1}$ PAM VU0486846 was highly selective for $\mathrm{M}_{1}$ against both human $\mathrm{M}_{2}-\mathrm{M}_{5}$ (Figure 4A) and rat $\mathrm{M}_{2}-\mathrm{M}_{5}$ (Figure 4B). While $\mathrm{M}_{1}$ VU0486846 had no interaction with the orthosteric site (Figure $4 \mathrm{C}$ ), i.e., no displacement of $\left[{ }^{3} \mathrm{H}\right]-\mathrm{NMS}$ binding, other $\mathrm{M}_{1}$ PAMs, such as $\mathbf{1}, \mathbf{2}, \mathbf{5}$, and $\mathbf{6}$, with reported adverse effect liability, show weak to significant displacement of $\left[{ }^{3} \mathrm{H}\right]-\mathrm{NMS}$, and in some cases found to possess negative cooperativity. 19,20,23,25,27-30 With regard to this parameter, we feel $\mathbf{M}_{1}$ PAMs should not interact with the orthosteric site, and that PAMs with negative cooperativity can present as procognitive efficacy (reversal of scopolamine-induced deficits) when, in reality, they are inducing a dose-dependent reversal of scopolamine binding. This is further supported by ligands such as $\mathbf{2}$, which failed to show efficacy in a rat novel object recognition (NOR) model, yet the same structural class of compounds were efficacious in scopolamine challenge models. $23,34,35$

Finally, prior to any further characterization, a high dose (100 mg/kg intraperitoneal (i.p.)) phenotypic mouse screen was performed to assess seizure liability, with a clean profile allowing a PAM to advance in development. Whereas seizure activity in mouse indicates over-stimulation of $\mathrm{M}_{1}$ (either too potent of an $\mathrm{M}_{1}$ PAM or robust ago-PAM), the latter are compounds not suitable for further advancement down the lead optimization work flow. ${ }^{22,26}$ VU0486846 was devoid of seizure liability in mice up to $3 \mathrm{~h}$ at a $100 \mathrm{mg} / \mathrm{kg}$ dose; by comparison, both $\mathbf{2}^{22}$ and $\mathbf{5}^{26}$ displayed Racine scale $4 / 5$ behavioral convulsions that develop rapidly and lasted for the $3 \mathrm{~h}$ duration of the study.

\section{Electrophysiology Studies in Layer V Medial Prefrontal Cortex (mPFC) Pyramidal Neurons Reveal That VU0486846, in Contrast to Other Ago-PAMs, Maintains the Activity- Dependence of Muscarinic Agonists}

A critical feature of an $\mathrm{M}_{1}$ PAM that appears to differentiate procognitive efficacy from cognitive disruption is agonist effects in a native system such as the rodent PFC. . $^{2023,25,27-30}$ As agonist activity in cell lines can be accentuated or disguised by the level of receptor expression, assessment in native systems is the ultimate arbiter. ${ }^{30}$ As we recently reported, 2 (MK-7622), 5 (PF-06764427), and 6 (PF-06827443) have agonist activity in the mouse PFC, which overactivates $M_{1}$ in the absence of endogenous ACh release and disrupts PFC function potentially leading to the observed lack of procognitive efficacy in rodent models. In contrast, pure $\mathrm{M}_{1}$ PAMs do not. ${ }^{23,30}$ Evaluation of VU0486846 in this same assay was shown to induce no significant change in field excitatory post synaptic potentials (fEPSPs) electrically evoked in layer II/III and recorded in layer V, and therefore maintain activity dependence of PFC function (Figure 5A). A submaximal concentration of the prototypical 
acetylcholine receptor (AChR) agonist carbachol $(10 \mu \mathrm{M})$ does not induce a significant longterm depression (LTD) of layer V fEPSPs (Figure 5B) as previously shown, ${ }^{23,25,30}$ but can be potentiated to a robust LTD by the $\mathrm{M}_{1}$ PAM VU0486846 (Figure 5C), similar to other previously reported $\mathrm{M}_{1}$ pure-PAMs such as VU0453595 25 and VU055164. ${ }^{23}$ Furthermore, at the ventral hippocampal-mPFC synapse, a pathway thought to be dysregulated in schizophrenia, ${ }^{36,37}$ a submaximal concentration $(3 \mu \mathrm{M})$ of the muscarinic acetylcholine receptor (mAChR) agonist oxotremorine-M (OxoM), does not induce a significant LTD of layer V fEPSPs evoked by optical stimulation of ventral hippocampal afferents (Figure 5D). However, VU0486846 can robustly potentiate the effects of $3 \mu \mathrm{M}$ OxoM to induce a substantial LTD at the ventral hippocampal-PFC synapse. A significant increase in the magnitude of LTD was observed with coapplication of $3 \mu \mathrm{M}$ VU0486846 $+10 \mu \mathrm{M} \mathrm{CCh}$ compared to $10 \mu \mathrm{M} \mathrm{CCh}$ alone $(p<0.05)$ (Figure 5F). In addition, the magnitude of LTD observed with coapplication of $10 \mu \mathrm{M}$ VU0486846 $+3 \mu \mathrm{M}$ OxoM compared to $3 \mu \mathrm{M}$ OxoM alone $(p<0.05)$ was also significantly enhanced (Figure $5 \mathrm{G})$. Therefore, in this native system, VU0486846 displays no agonist activity on its own but can potentiate the effects of cholinergic agonists and thus holds promise for utility as an in vivo tool to assess the procognitive efficacy of $\mathrm{M}_{1}$ PAMs in rodent models.

\section{Drug Metabolism Studies}

Due to the differentiated pharmacological profile of VU0486846 (16) from the other $\mathrm{M}_{1}$ PAMs (Figure 1), ${ }^{19,20,23,25,27-30}$ we evaluated VU0486846 in a battery of in vitro and in vivo drug metabolism and pharmacokinetic (DMPK) assays. VU0486846 was predicted to be a low to moderately cleared compound in hepatic microsomes (human $\mathrm{CL}_{\mathrm{hep}}=11.1$ $\mathrm{mL} / \mathrm{min} / \mathrm{kg}$; rat $\mathrm{CL}_{\text {hep }}=23 \mathrm{~mL} / \mathrm{min} / \mathrm{kg}$; cyno $\mathrm{CL}_{\text {hep }}=43 \mathrm{~mL} / \mathrm{min} / \mathrm{kg}$ ) with attractive fraction unbound in plasma (human $f_{\mathrm{u}}=0.12$, rat $f_{\mathrm{u}}=0.11$, cyno $f_{\mathrm{u}}=0.016$ ) and rat brain homogenate $\left(f_{\mathrm{u}}=0.03\right)$. The $\mathrm{CYP}_{450}$ profile was acceptable for a tool compound (3A4 $\mathrm{IC}_{50}$ $\left.=5.0 \mu \mathrm{M} ; 1 \mathrm{~A} 2 \mathrm{IC}_{50}>30 \mu \mathrm{M} ; 2 \mathrm{C} 9 \mathrm{IC}_{50}=18.8 \mu \mathrm{M} ; 2 \mathrm{D} 6 \mathrm{IC}_{50}=29.8 \mu \mathrm{M}\right)$, but precluded further advancement as a putative clinical candidate due to the inhibition of 3A4. Like other $\mathrm{M}_{1}$ PAMs harboring the (1S,2S)-2-aminocyclohexan-1-ol amide moiety, CNS exposure varied across rodent species (rat $K_{\mathrm{p}}=0.18, K_{\mathrm{p} \text {,uu }}=0.05$; mouse $K_{\mathrm{p}}=0.67 ; K_{\mathrm{p} \text {,uu }}=0.17$ ), but the compound was not a human P-gp substrate $\left(\mathrm{MDCK}\right.$ ER $=0.9, P_{\text {app }}=30 \times 10^{-6}$ $\mathrm{cm} / \mathrm{s}$ ). In vivo PK for VU0486846 was evaluated in both rats and nonhuman primates. From a standard rat PK IV/PO crossover study, VU0486846 showed high clearance $\left(\mathrm{CL}_{\mathrm{p}}=89\right.$ $\mathrm{mL} / \mathrm{min} / \mathrm{kg}$ ) and a lack of an in vitro:in vivo correlation (IVIVC) from predicted in vitro parameters. 16 also displayed a $1.2 \mathrm{~h}$ half-life, a reasonable volume $\left(V_{\mathrm{ss}}=1.8 \mathrm{~L} / \mathrm{kg}\right)$, and excellent oral bioavailability $(\% \mathrm{~F}=95.9)$ in rat. A similarly designed study in male cynomolgus monkey was more favorable, with a $4.2 \mathrm{~h}$ half-life, moderate clearance $\left(\mathrm{CL}_{\mathrm{p}}=\right.$ $18 \mathrm{~mL} / \mathrm{min} / \mathrm{kg}$ ), good volume ( $V_{\mathrm{ss}}=1 \mathrm{~L} / \mathrm{kg}$ ), and good oral bioavailability ( $\% \mathrm{~F}=37$ ) from the amorphous solid. No adverse events or cholinergic side effects were noted in these PK studies. While VU0486846 was highly selective versus $\mathrm{M}_{2}-\mathrm{M}_{5}$, we wanted a broader assessment of ancillary pharmacology prior to initiating extensive in vivo studies. Evaluation of VU0486846 in a Eurofins Lead Profiling panel of 68 GPCRs, ion channels, and transporters revealed no significant activity at any target in the panel (no inhibition $>50 \%$ @ $10 \mu \mathrm{M}) .{ }^{32}$ Thus, we were ready to assess the behavioral pharmacology of a structurally novel $\mathrm{M}_{1}$ PAM with good CNS penetration, an attractive DMPK profile, devoid of agonist 
activity in the PFC, and free from seizure/cholinergic liability in mouse, the most sensitive species.

\section{Behavioral Pharmacology Assessment}

Prior to behavioral pharmacology assessment for efficacy of the novel $\mathrm{M}_{1}$ PAM VU0486846, we evaluated the potential of VU0486846 to produce cholinergic or CNS adverse events in both mice and rats. Thus, we performed a Modified Irwin Toxicology Battery (Supporting Figure 2) ${ }^{32}$ test in mice dosed at $100 \mathrm{mg} / \mathrm{kg}$ i.p., which mirrored the mouse seizure study. Over the $3 \mathrm{~h}$ evaluation period, VU0486846 did not produce any cholinergic side effects or pronounced adverse effects in mice, as opposed to nonselective muscarinic agonists and $\mathrm{M}_{1}$ ago-PAMs ${ }^{23,27}$ Moreover, exposure from this study was more than sufficient to elicit adverse pharmacology. Here, total plasma levels reached $18.2 \mu \mathrm{M}$ (30x above the mouse $\mathrm{EC}_{50}$ ), free plasma levels were $2 \mu \mathrm{M}$, with correlating high brain levels (total brain reached $12.2 \mu \mathrm{M}$, free brain levels were $342 \mathrm{nM}$ ). A similar Modified Irwin Toxicology Battery (Supporting Figure 3 ) 32 test in rats was also performed at 56.6 $\mathrm{mg} / \mathrm{kg}$ i.p, and, as with mouse, VU0486846 did not produce any cholinergic side effects or pronounced adverse effects in rats, as opposed to nonselective muscarinic agonists/ $\mathrm{M}_{1}$ agoPAMs, over the $3 \mathrm{~h}$ evaluation period. Here, total terminal plasma exposure reached $4.4 \mu \mathrm{M}$ ( $489 \mathrm{nM}$ free) with acceptable brain levels ( $1.15 \mu \mathrm{M}$ total, $32 \mathrm{nM}$ free). We attempted a related nonhuman primate (NHP) assessment, but the physiochemical properties and exposure limitations of VU0486846 precluded definitive data; however, we achieved total plasma levels in NHP of $\sim 2 \mu \mathrm{M}$, without any adverse effects. The physiochemical properties of VU0486846 did not allow for higher dose formulations, and is another limitation, beyond 3A4 inhibition, that precluded further development toward a clinical candidate.

Previously, we demonstrated that $\mathrm{M}_{1}$ PAMs with no agonist activity in native systems (PFC), afforded robust efficacy in the novel object recognition (NOR) paradigm, whereas $\mathrm{M}_{1}$ PAMs and ago-PAMs with agonist activity in the PFC showed little efficacy in NOR. ${ }^{23,27,30}$ As shown in Figure 6A, PAM VU0486846 dose-dependently enhanced recognition memory in rats, with a minimum effective dose of $3 \mathrm{mg} / \mathrm{kg}$ i.p $\left(\mathrm{n}=12 ; \mathrm{p}=0.0133 ; \mathrm{F}=4 ; \mathrm{R}^{2}=0.2143\right)$. Thus, suggesting that VU0486846 could serve as an $M_{1}$ PAM to investigate efficacy in other models of cognition. The cognitive and negative symptom clusters of schizophrenia are a major focus of our lab. However, a major unmet need in the schizophrenia patient population is the added cognitive dysfunction induced by standard atypical antipsychotics., ${ }^{38-40}$ Indeed, first line agents, such as risperidone, are known to engender cognitive deficits in humans (and in rodent models), where cognitive dysfunction is already a major symptom of the disease. ${ }^{38-41}$ In Figure 6B, we show for the first time that an $\mathrm{M}_{1}$ PAM can reverse the cognitive deficits induced by risperidone $\left(n=11-13 ; p<0.0001 ; \mathrm{F}=6.682 ; R^{2}=0.3430\right.$ ), and suggest coadministration of an $\mathrm{M}_{1}$ PAM with an atypical antipsychotic might attenuate cognitive impairments in schizophrenia patients. In these studies, VU0486846 dosedependently reversed risperidone-induced deficits in acquisition of contextual fear conditioning. When coadministered with $3 \mathrm{mg} / \mathrm{kg}$ risperidone, $10 \mathrm{mg} / \mathrm{kg}$ VU0486846 restored conditioned freezing to vehicle-treated control levels, with a minimum effective dose (MED) of $1 \mathrm{mg} / \mathrm{kg}$. Future efforts will evaluate the cognitive dysfunction induced by other typical/atypical antipsychotics and the ability of VU0486846 to reverse these deficits. 


\section{CONCLUSIONS}

Here we report the discovery of a novel $\mathrm{M}_{1}$ PAM with enhanced potency, physiochemical properties, and DMPK profile to assess $\mathrm{M}_{1}$ function in CNS disorders. VU0486846 is a highly selective, potent $\mathrm{M}_{1}$ PAM, devoid of agonist activity in the PFC, as well as cholinergic or other adverse effects in mice, rats and NHP, which results in robust procognitive activity in rodent models. These data afford the community a new in vivo tool compound to study $\mathrm{M}_{1}$ PAM activity in mouse and rat models, as well as supporting the pursuit of $\mathrm{M}_{1}$ PAMs as either a monotherapy to enhance cognitive function or has an adjunct therapy with current standard of care therapies for individuals suffering from cognitive deficits, such as schizophrenia patients. Further studies with VU0486846 (16) are underway and will be reported in due course.

\section{METHODS}

\section{Chemical Synthesis and Purification}

All ${ }^{1} \mathrm{H}$ NMR and ${ }^{13} \mathrm{C}$ NMR spectra were recorded on a Bruker AV-400 (400 MHz) or Bruker AV-NMR (600 MHz) instrument. Chemical shifts are reported in ppm relative to residual solvent peaks as an internal standard set to $\delta \mathrm{H} 7.26$ or $\delta \mathrm{C} 77.0\left(\mathrm{CDCl}_{3}\right)$ and $\delta \mathrm{H}$ 3.31 or $\delta \mathrm{C} 49.0\left(\mathrm{CD}_{3} \mathrm{OD}\right)$. Data are reported as follows: chemical shift, multiplicity ( $\mathrm{s}=$ singlet, $\mathrm{d}=$ doublet, $\mathrm{t}=$ triplet, $\mathrm{q}=$ quartet, $\mathrm{br}=$ broad, $\mathrm{m}=$ multiplet), integration, and coupling constant $(\mathrm{Hz})$. IR spectra were recorded as thin films and are reported in wavenumbers $\left(\mathrm{cm}^{-1}\right)$. Low resolution mass spectra were obtained on an Agilent 1200 LCMS with electrospray ionization. High resolution mass spectra were recorded on a Waters QtofAPI-US plus Acquity system. The value $\Delta$ is the error in the measurement (in ppm) given by the equation $\Delta=[(\mathrm{ME}-\mathrm{MT}) / \mathrm{MT}] \times 106$, where ME is the experimental mass and MT is the theoretical mass. The HRMS results were obtained with ES as the ion source and leucine enkephalin as the reference. Optical rotations were measured on a PerkinElmer-341 polarimeter. Analytical thin layer chromatography was performed on $250 \mu \mathrm{M}$ silica gel 60 F254 plates. Visualization was accomplished with UV light, and/or the use of ninhydrin, anisaldehyde and ceric ammonium molybdate solutions followed by charring on a hot-plate. Chromatography on silica gel was performed using Silica Gel 60 (230-400 mesh) from Sorbent Technologies. Analytical HPLC was performed on an Agilent 1200 analytical LCMS with UV detection at 214 and $254 \mathrm{~nm}$ along with ELSD detection. Solvents for extraction, washing, and chromatography were HPLC grade. All reagents were purchased from Aldrich Chemical Co. and were used without purification. All polymer-supported reagents were purchased from Biotage, Inc. Flame-dried (under vacuum) glassware was used for all reactions. All reagents and solvents were commercial grade and purified prior to use when necessary. High-resolution mass spectrometry (HRMS) data were obtained using a Micromass Q-Tof API-US mass spectrometer.

Ethyl 3,4-Dihydro-2H-1,4-benzoxazine-2-carboxylate (10)-A solution of 2aminophenol (15740 mg, $144.28 \mathrm{mmol})$, potassium carbonate $(33717 \mathrm{mg}, 240.46 \mathrm{mmol})$, ethyl 2,3-dibromopropionate $(25000 \mathrm{mg}, 96.18 \mathrm{mmol})$, and acetonitrile $(300 \mathrm{~mL})$ was heated to $80{ }^{\circ} \mathrm{C}$ and was allowed to stir for $16 \mathrm{~h}$. The reaction was diluted with water and extracted 
with EtOAc (3x). The layers were separated, and the organic phases were combined, washed with brine (1×), dried with $\mathrm{MgSO}_{4}$, filtered, and concentrated in vacuo. Crude product was purified by flash chromatography (Teledyne ISCO Combi-Flash system, 0-30\% EtOAc in hexanes) to provide a brown oil (14595 mg, $70.43 \mathrm{mmol}, 73 \%$ yield). ${ }^{1} \mathrm{H}$ NMR (400 MHz, $\left.\mathrm{CDCl}_{3}\right) \delta 6.93(\mathrm{dd}, J=7.92 \mathrm{~Hz}, 1.4 \mathrm{~Hz}, 1 \mathrm{H}), 6.79(\mathrm{td}, J=7.5 \mathrm{~Hz}, 1.4 \mathrm{~Hz}, 1 \mathrm{H}), 6.72(\mathrm{td}, J=$ $7.6 \mathrm{~Hz}, 1.6 \mathrm{~Hz}, 1 \mathrm{H}), 6.61(\mathrm{dd}, J=7.7 \mathrm{~Hz}, 1.6 \mathrm{~Hz}, 1 \mathrm{H}), 4.81-4.79(\mathrm{~m}, 1 \mathrm{H}), 4.26(\mathrm{~m}, 2 \mathrm{H})$, 3.63-3.55 (m, 2H), $1.28(\mathrm{t}, J=7.2,3 \mathrm{H}) .{ }^{13} \mathrm{C} \mathrm{NMR}\left(100 \mathrm{MHz}, \mathrm{CDCl}_{3}\right) \delta 169.4,142.9$, 132.6, 121.6, 119.5, 116.9, 115.7, 72.7, 61.5, 42.6, 14.1 ppm. HRMS (TOF, ES+) calcd for $\mathrm{C}_{11} \mathrm{H}_{13} \mathrm{NO}_{3}, 207.0895$; found, 207.0892 .

\section{Ethyl 4-[(4-Bromophenyl)methyl]-2,3-dihydro-1,4-benzoxazine-2-carboxylate}

(11)-A solution of ethyl 3,4-dihydro-2 $H$-benzo[b]-[1,4]oxazine-2-carboxylate (2165 mg, $10.45 \mathrm{mmol}$ ), potassium carbonate (1831 mg, $13.06 \mathrm{mmol})$, 4-bromobenzyl bromide (3263.88 mg, $13.06 \mathrm{mmol})$, and acetonitrile $(18 \mathrm{~mL})$ was heated to $80^{\circ} \mathrm{C}$ and allowed to stir for $16 \mathrm{~h}$. The reaction was diluted with water and extracted with EtOAc (3x). The layers were separated and the organic phases were combined, washed with brine $(1 \times)$, dried over $\mathrm{MgSO}_{4}$, filtered, and concentrated in vacuo. Crude product was purified using flash chromatography (Teledyne ISCO Combi-Flash system 0-40\% EtOAc in hexanes) to provide an off white solid (2935 mg, $7.80 \mathrm{mmol}, 74 \%$ yield). ${ }^{1} \mathrm{H}$ NMR (400 MHz, $\left.\mathrm{CDCl}_{3}\right) \delta 7.45$ (d, $J=8.4 \mathrm{~Hz}, 2 \mathrm{H}), 7.14(\mathrm{~d}, J=8.3 \mathrm{HZ}, 2 \mathrm{H}), 6.97(\mathrm{dd}, J=7.9 \mathrm{~Hz}, 1.5 \mathrm{~Hz}, 1 \mathrm{H}), 6.80(\mathrm{td}, J=7.7$ $\mathrm{Hz}, 1.5 \mathrm{~Hz}, 1 \mathrm{H}), 6.72(\mathrm{td}, J=7.6 \mathrm{~Hz}, 1.4 \mathrm{~Hz}, 1 \mathrm{H}), 6.61(\mathrm{dd}, J=8.0 \mathrm{~Hz}, 1.3 \mathrm{~Hz}, 1 \mathrm{H}), 4.83(\mathrm{t}$, $J=4.0 \mathrm{~Hz}, 1 \mathrm{H}), 4.45-4.17(\mathrm{~m}, 4 \mathrm{H}), 3.51(\mathrm{~d}, J=4.1 \mathrm{~Hz}, 2 \mathrm{H}), 1.25(\mathrm{t}, J=7.1 \mathrm{~Hz}, 3 \mathrm{H}) .{ }^{13} \mathrm{C}$ NMR (100 MHz, $\left.\mathrm{CDCl}_{3}\right) \delta 169.2,142.9,136.7,134.4,131.7,128.7,121.8,121.0,119.0$, 116.6, 112.8, 72.5, 61.6, 54.4, 48.6, 14.1 ppm. HRMS (TOF, ES+) calcd for $\mathrm{C}_{18} \mathrm{H}_{18} \mathrm{BrNO}_{3}$, 375.0470; found, 375.0467 .

4-[(4-Bromophenyl)methyl]-2,3-dihydro-1,4-benzoxazine-2-carboxylic acid (12) -A solution of ethyl 4-[(4-bromophenyl)methyl]-2,3-dihydro-1,4-benzoxazine-2carboxylate (2935 mg, $7.8 \mathrm{mmol}$ ), potassium hydroxide (437.7 mg, $7.8 \mathrm{mmol})$, THF (16 $\mathrm{mL})$, and Water $(8 \mathrm{~mL})$ was heated to $60{ }^{\circ} \mathrm{C}$ and allowed to stir for $3 \mathrm{~h}$. The reaction was diluted in water, acidified to $\mathrm{pH}=3$, extracted with EtOAc (3x), and concentrated in vacuo to afford the desired material, which was carried forward to the next step without any further purification (2715 mg, quantitative yield). ${ }^{1} \mathrm{H} \mathrm{NMR}\left(400 \mathrm{MHz}, \mathrm{CDCl}_{3}\right) \delta 7.40(\mathrm{~d}, J=8.3$ $\mathrm{Hz}, 2 \mathrm{H}), 7.13(\mathrm{~d}, J=8.2 \mathrm{~Hz}, 2 \mathrm{H}), 6.96(\mathrm{dd}, J=7.8 \mathrm{~Hz}, 1.4 \mathrm{~Hz}, 1 \mathrm{H}), 6.82(\mathrm{td}, J=8.0 \mathrm{~Hz}, 1.4$ $\mathrm{Hz}, 1 \mathrm{H}), 6.73$ (td, $J=7.4 \mathrm{~Hz}, 1.4 \mathrm{~Hz}, 1 \mathrm{H}), 6.63(\mathrm{dd}, J=8.0 \mathrm{~Hz}, 1.1 \mathrm{~Hz}, 1 \mathrm{H}), 4.90$ (t, $J=3.8$, $1 \mathrm{H}), 4.44-4.28(\mathrm{~m}, 2 \mathrm{H}), 3.52(\mathrm{~d}, J=3.80 \mathrm{~Hz}, 2 \mathrm{H}) .{ }^{13} \mathrm{C} \mathrm{NMR}\left(100 \mathrm{MHz}, \mathrm{CDCl}_{3}\right) \delta 174.4$, 142.7, 136.5, 134.5, 131.9, 129.0, 122.3, 121.3, 119.4, 116.8, 113.2, 72.4, 54.6, 48.4 ppm. HRMS (TOF, ES+) calc'd for $\mathrm{C}_{16} \mathrm{H}_{14} \mathrm{BrNO}_{3}, 347.0157$; found, 347.0150 .

4-[(4-Bromophenyl)methyl]-N-[(1S,2S)-2-hydroxycyclohexyl]-2,3-dihydro-1,4benzoxazine-2 carboxamide (13)—A solution of 4-[(4-bromophenyl)methyl]-2,3dihydro-1,4-benzoxazine-2-carboxylic acid (2700 mg, $7.75 \mathrm{mmol}), \mathrm{N}, \mathrm{N}$ diisopropylethylamine (6.08 $\mathrm{mL}, 34.89 \mathrm{mmol})$, HATU (3243.3 $\mathrm{mg}, 8.53 \mathrm{mmol})$, and DMF $(18 \mathrm{~mL})$ was prestirred for $10 \mathrm{~min}$, to which was then added $(1 S, 2 S)$-2-aminocyclohexanol (1071.69 mg, $9.31 \mathrm{mmol}$ ) and the reaction was allowed to stir at room temperature for $12 \mathrm{~h}$. 
The reaction was diluted with water and extracted with EtOAc (3x). The layers were separated and the combined organics were washed with brine (1×), dried over $\mathrm{MgSO}_{4}$, filtered, and concentrated in vacuo. Crude product was purified using flash chromatography (Teledyne ISCO Combi-Flash system, $0-5 \% \mathrm{MeOH}$ in DCM) to provide an off white solid (2785 mg, $6.2535 \mathrm{mmol}, 80 \%$ yield, 8:1 dr)). ${ }^{1} \mathrm{H}$ NMR (400 MHz, $\left.\mathrm{CDCl}_{3}\right) \delta 7.44(\mathrm{~d}, J=8.3$ $\mathrm{Hz}, 2 \mathrm{H}), 7.16(\mathrm{~d}, J=8.3 \mathrm{~Hz}, 2 \mathrm{H}), 6.92(\mathrm{dd}, J=7.9 \mathrm{~Hz}, 1.3 \mathrm{~Hz}, 1 \mathrm{H}), 6.83(\mathrm{td}, J=7.7 \mathrm{~Hz}, 1.3$ $\mathrm{Hz}, 1 \mathrm{H}), 6.70(\mathrm{td}, J=7.7 \mathrm{~Hz}, 1.2 \mathrm{~Hz}, 1 \mathrm{H}), 6.63(\mathrm{dd}, J=8.1 \mathrm{~Hz}, 1.1 \mathrm{~Hz}, 1 \mathrm{H}), 6.50(\mathrm{~d}, J=7.4$ $\mathrm{Hz}, 1 \mathrm{H}), 4.72(\mathrm{dd}, J=6.7 \mathrm{~Hz}, 2.9 \mathrm{~Hz}, 1 \mathrm{H}), 4.43-4.42(\mathrm{~m}, 2 \mathrm{H}), 3.72-3.63(\mathrm{~m}, 1 \mathrm{H}), 3.59(\mathrm{dd}$, $J=11.9 \mathrm{~Hz}, 3.0 \mathrm{~Hz}, 1 \mathrm{H}), 3.51-3.46(\mathrm{~m}, 1 \mathrm{H}), 3.28-3.23(\mathrm{~m}, 1 \mathrm{H}), 2.06-1.97(\mathrm{~m}, 2 \mathrm{H}), 1.77-$ $1.69(\mathrm{~m}, 2 \mathrm{H}), 1.38-1.17(\mathrm{~m}, 5 \mathrm{H}) .{ }^{13} \mathrm{C}$ NMR $\left(100 \mathrm{MHz}, \mathrm{CDCl}_{3}\right) \delta 170.2,141.9,136.5$, 134.8, 131.8, 128.8, 122.6, 121.0, 118.6, 116.3, 113.2, 74.9, 73.8, 55.5, 54.7, 49.0, 34.1, 31.2, 24.4, 23.8 ppm. HRMS (TOF, ES+) calcd for $\mathrm{C}_{22} \mathrm{H}_{25} \mathrm{BrN}_{2} \mathrm{O}_{3}, 444.1049$; found, 444.1048 .

\section{(2R)-N-[(1S,2S)-2-Hydroxycyclohexyl]-4-[(4-pyrazol-1-ylphenyl)-methyl]-2,3-} dihydro-1,4-benzoxazine-2-carboxamide (VU0486846, 16)—A degassed solution of 4-[(4-bromophenyl)methyl]- $N$-[(1S,2S)-2-hydroxycyclohexyl]-2,3-dihydro-1,4benzoxazine-2-carboxamide (900 mg, $2.02 \mathrm{mmol}$ ), pyrazole (192.61 $\mathrm{mg}, 2.83 \mathrm{mmol}$ ), potassium phosphate (943.74 mg, $4.45 \mathrm{mmol}$ ), copper(I) iodide (115.46 mg, $0.61 \mathrm{mmol}$ ), trans- $N, N^{\prime}$-dimethylcyclohexane-2-diamine $(0.09 \mathrm{~mL}, 0.61 \mathrm{mmol})$, and 1,4-dioxane (6.7 $\mathrm{mL}$ ) was heated to $100{ }^{\circ} \mathrm{C}$ and was allowed to stir for $24 \mathrm{~h}$. The reaction was diluted in water and extracted with EtOAc (3x). The layers were separated, and the organic phases were combined, washed with saturated $\mathrm{NH}_{4} \mathrm{Cl}(1 \times)$ and saturated brine (1×), dried over $\mathrm{MgSO}_{4}$, filtered, and concentrated in vacuo. Crude product was purified using flash chromatography (Teledyne ISCO Combi-Flash system, 0-60\% EtOAc in hexanes) to provide a white solid (219 mg, $0.506 \mathrm{mmol}, 25 \%$ yield). ${ }^{1} \mathrm{H} \mathrm{NMR}\left(400 \mathrm{MHz}, \mathrm{CDCl}_{3}\right) \delta 7.89(\mathrm{~d}, J=2.3 \mathrm{~Hz}, 1 \mathrm{H})$, $7.70(\mathrm{~d}, J=1.2 \mathrm{~Hz}, 1 \mathrm{H}), 7.64(\mathrm{~d}, J=8.5 \mathrm{~Hz}, 2 \mathrm{H}), 7.36(\mathrm{~d}, J=8.4 \mathrm{~Hz}, 2 \mathrm{H}), 6.91(\mathrm{dd}, J=8.2$ $\mathrm{Hz}, 1.0 \mathrm{~Hz}, 1 \mathrm{H}), 6.84(\mathrm{td}, J=8.2 \mathrm{~Hz}, 1.2 \mathrm{~Hz}, 1 \mathrm{H}), 6.73-6.68(\mathrm{~m}, 2 \mathrm{H}), 6.52(\mathrm{~d}, J=7.5 \mathrm{~Hz}$, $1 \mathrm{H}), 6.44(\mathrm{t}, J=2.0 \mathrm{~Hz}, 1 \mathrm{H}), 4.73(\mathrm{dd}, J=6.7 \mathrm{~Hz}, 2.9 \mathrm{~Hz}, 1 \mathrm{H}), 4.51-4.40(\mathrm{~m}, 2 \mathrm{H}), 3.73-$ $3.61(\mathrm{~m}, 2 \mathrm{H}), 3.53-3.39(\mathrm{~m}, 1 \mathrm{H}), 3.30-3.24(\mathrm{~m}, 1 \mathrm{H}), 2.01(\mathrm{~d}, J=10.9 \mathrm{~Hz}, 2 \mathrm{H}), 1.76-1.68$ (m, 2H), 1.38-1.20 (m, 5H). ${ }^{13} \mathrm{C}$ NMR (100 MHz, $\left.\mathrm{CDCl}_{3}\right) \delta 170.3,142.0,140.9,139.4$, 135.7, 134.9, 128.1, 126.7, 122.6, 119.5, 118.5, 116.2, 113.3, 107.5, 74.8, 73.8, 55.5, 54.8, 49.0, 34.1, 31.2, 24.4, 23.8 ppm. HRMS (TOF, ES+) calcd for $\mathrm{C}_{25} \mathrm{H}_{28} \mathrm{~N}_{4} \mathrm{O}_{3}, 432.2161$; found, 432.2161; $[a] \mathrm{D}^{21}+58.571(c=0.91, \mathrm{MeOH})$.

\section{Cell Lines}

Chinese hamster ovary (CHO) cells stably expressing muscarinic receptor isoforms were maintained in Ham's F-12 growth medium containing 10\% FBS, 20 mM HEPES, antibiotic/ antimycotic, $500 \mu \mathrm{g} / \mathrm{mL} \mathrm{G} 418$ in the presence of $5 \% \mathrm{CO}_{2}$ at $37{ }^{\circ} \mathrm{C}$. For Gi-coupled $\mathrm{M}_{2}$ and $\mathrm{M}_{4}$ receptors, chimeric Gqi5 was stably coexpressed to elicit Ca response. To determine the functional activity at $\operatorname{dog} \mathrm{M}_{1}$, the $\operatorname{dog} \mathrm{M}_{1}$ full-length open reading frame (ORF) was amplified from the dog hippocampus cDNAs (Zyagen, San Diego, CA). The ORF was then subcloned into the EcoR I and Xho I sites of pcDNA3.1 (+) vector (Life Technologies, Carlsbad, CA). Sequencing of the plasmid confirmed the presence of $\operatorname{dog} \mathrm{M}_{1}$ ORF (XM_540897). CHO cells were transfected with dog $\mathrm{M}_{1}$ expression plasmid using Fugene 6 
(Promega, Madison, WI), the transfected cells were incubated with the selection medium containing $1 \mathrm{mg} / \mathrm{mL}$ G418 for 2 weeks, and the resulting polyclones were used for the calcium mobilization assay described below.

\section{Calcium Mobilization Assay}

To determine the potency and efficacy of $\mathrm{M}_{1}$ ago-PAMs, calcium flux was measured using the Functional Drug Screening System (FDSS7000, Hamamatsu, Japan) as previously described (Rook et al. 2016). Briefly, All muscarinic receptor-CHO cells including multi species $\mathrm{M}_{1}$ and $\mathrm{M}_{2}-\mathrm{M}_{5}$ cells were plated in black-walled, clear-bottomed 384 well plates (Greiner Bio-One, Monroe, NC) at 20,000 cells/well in $20 \mu \mathrm{L}$ of growth medium without G418 the day before assay. The following day, cells were washed with assay buffer (Hank's balanced salt solution, $20 \mathrm{mM}$ HEPES, and $2.5 \mathrm{mM}$ probenecid) and immediately incubated with $20 \mu \mathrm{L}$ of $1.15 \mu \mathrm{M}$ fluo-4-acetomethoxyester (Fluo-4 AM) dye solution prepared in assay buffer for $45 \mathrm{~min}$ at $37^{\circ} \mathrm{C}$. During the incubation time, all compounds were serial diluted (1:3) in DMSO for 10 point concentration-response curves (CRC), and further diluted in assay buffer at starting final concentration $30 \mu \mathrm{M}$ using Echo liquid handler (Labcyte, Sunnyvale CA). Dye was removed and replaced with assay buffer. Immediately, calcium flux was measured using the FDSS7000. The CRC of compounds or vehicle was added to cells for $2.5 \mathrm{~min}$ and then an $\mathrm{EC}_{20}$ concentration of acetylcholine ( $\mathrm{ACh}$ ) was added and incubated for $1 \mathrm{~min}$. $\mathrm{EC}_{\max }$ concentration was also added to cells that were incubated with DMSO vehicle to calculate the $\mathrm{EC}_{20}$ calcium response. Using a four point logistical equation in GraphPad Prism 5.0 (GraphPad Software, Inc., La Jolla, CA), the concentration response curves were generated for determination of the potency and efficacy of the agonist and PAM.

\section{Radioligand Binding Assay}

Competition binding assays were performed using $\left[{ }^{3} \mathrm{H}\right]-N$-methylscopolamine $\left(\left[{ }^{3} \mathrm{H}-\right] \mathrm{NMS}\right.$, PerkinElmer. Boston, MA) as previously described. Briefly, compounds were serial diluted 1:3 in DMSO for an 11 point CRC, then further diluted for a final top concentration of 30 $\mu \mathrm{M}$ in binding buffer (20 mM HEPES, $10 \mathrm{mM} \mathrm{MgCl}$, and $100 \mathrm{mM} \mathrm{NaCl}, \mathrm{pH}$ 7.4). Membranes from rat $\mathrm{M}_{1}-\mathrm{CHO}$ cells $(10 \mu \mathrm{g})$ were incubated with the serial diluted compounds in the presence of a $K_{\mathrm{d}}$ concentration of [ $\left.{ }^{3} \mathrm{H}-\right] \mathrm{NMS}, 0.088 \mathrm{nM}$, at room temperature for $1 \mathrm{~h}$ with constant shaking. Nonspecific binding was determined in the presence of $10 \mu \mathrm{M}$ atropine. Binding was terminated by rapid filtration through GF/B Unifilter plates (PerkinElmer) using a Brandel 96-well plate Harvester (Brandel Inc., Gaithersburg, MD), followed by three washes with ice-cold harvesting buffer ( $25 \mathrm{mM}$ Tris$\mathrm{HCl}, \mathrm{pH} 7.4,150 \mathrm{mM} \mathrm{NaCl}$ ). Plates were air-dried overnight, $50 \mu \mathrm{L}$ of Microscint20 added to the plate, and radioactivity was counted using a TopCount Scintillation Counter (PerkinElmer Life and Analytical Sciences).

\section{Drug Metabolism Methods}

In Vitro-Protein binding of $\mathrm{M}_{1}$ PAMs was determined in plasma via equilibrium dialysis employing Single-Use RED Plates with inserts (ThermoFisher Scientific, Rochester, NY). Briefly plasma ( $220 \mu \mathrm{L}$ ) was added to the 96 -well plate containing test article $(5 \mu \mathrm{L})$ and 
mixed thoroughly. Subsequently, $200 \mu \mathrm{L}$ of the plasma-test article mixture was transferred to the cis chamber (red) of the RED plate, with an accompanying $350 \mu \mathrm{L}$ of phosphate buffer ( $25 \mathrm{mM}, \mathrm{pH}$ 7.4) in the trans chamber. The RED plate was sealed and incubated $4 \mathrm{~h}$ at $37^{\circ} \mathrm{C}$ with shaking. At completion, $50 \mu \mathrm{L}$ aliquots from each chamber were diluted 1:1 (50 $\mu \mathrm{L})$ with either plasma (cis) or buffer (trans) and transferred to a new 96-well plate, at which time ice-cold acetonitrile ( 2 volumes) was added to extract the matrices. The plate was centrifuged (3000 rpm, $10 \mathrm{~min}$ ), and supernatants were transferred to a new 96-well plate. The sealed plate was stored at $-20{ }^{\circ} \mathrm{C}$ until LC/MS/MS analysis.

A cocktail of substrates for cytochrome P450 enzymes (1A2: phenacetin, $10 \mu \mathrm{M} ; 2 \mathrm{C} 9$ : diclofenac, $5 \mu \mathrm{M}$; 2D6: dextromethorphan, $5 \mu \mathrm{M}$; 3A4: midazolam, $2 \mu \mathrm{M})$ were mixed to assess the ability of compounds to inhibit the major cytochrome $\mathrm{P} 450$ enzymes. A reaction mixture of $100 \mathrm{mM} \mathrm{Kpi,} \mathrm{pH} \mathrm{7.4,} 0.1 \mathrm{mg} / \mathrm{mL}$ human liver microsomes (HLM) and Substrate Mix was prepared and aliquoted into a 96-deep-well block. Test compound and positive control (in duplicate) were then added such that the final concentration of test compound ranged from $0.1-30 \mu \mathrm{M}$. The plate was vortexed briefly and then preincubated at $37{ }^{\circ} \mathrm{C}$ while shaking for $15 \mathrm{~min}$. The reaction was initiated with the addition of NADPH (1 mM final concentration). The incubation continued for $8 \mathrm{~min}$ and the reaction quenched by $2 \mathrm{x}$ volume of cold acetonitrile containing internal standard ( $50 \mathrm{nM}$ carbamazepine). The plate was centrifuged for $10 \mathrm{~min}\left(4000 \mathrm{rcf}, 4^{\circ} \mathrm{C}\right)$ and the resulting supernatant diluted 1:1 with water for LC/MS/MS analysis. A 12 point standard curve of substrate metabolites over the range of $0.98 \mathrm{nM}$ to $2000 \mathrm{nM}$. The $\mathrm{IC}_{50}$ values for each compound were obtained for the individual CYP enzymes by quantitating the inhibition of metabolite formation for each probe substrate. A $0 \mu \mathrm{M}$ compound condition (or control) was set to $100 \%$ enzymatic activity and the effect of increasing test compound concentrations on enzymatic activity could then be calculated from the \% of control activity. Curves were fitted using XLfit 5.2.2 (four-parameter logistic model, eq 201) to determine the concentration that produces halfmaximal inhibition $\left(\mathrm{IC}_{50}\right)$.

The in vitro biotransformation of compounds was investigated using hepatic microsomes incubated with or without NADPH $(1 \mathrm{mM})$. Reactions were terminated by adding 1 volume of acetonitrile, and proteins were removed by centrifugation. The supernatants were saved for HPLC/UV/MS analysis. Samples were analyzed on a Waters Acquity UPLC system with PDA detector with a flow rate of $0.5 \mathrm{~mL} / \mathrm{min}$ (A: Water/Acetonitrile $95 / 5$ with $0.1 \%$ formic acid; B: Acetonitrile) and a Waters Xevo QTOF mass spectrometer with positive ESI source.

The metabolic stability of $\mathrm{M}_{1}$ PAMs was investigated in multispecies hepatic microsomes (BD Biosciences, Billerica, MA) using substrate depletion methodology (\% test article remaining). A potassium phosphate-buffered reaction mixture (0.1 M, pH 7.4) of test article $(1 \mu \mathrm{M})$ and microsomes $(0.5 \mathrm{mg} / \mathrm{mL})$ was preincubated $(5 \mathrm{~min})$ at $37^{\circ} \mathrm{C}$ prior to the addition of NADPH ( $1 \mathrm{mM})$. The incubations, performed in 96-well plates, were continued at $37^{\circ} \mathrm{C}$ under ambient oxygenation and aliquots $(80 \mu \mathrm{L})$ were removed at selected time intervals $(0$, $3,7,15,25$, and $45 \mathrm{~min}$ ). Protein was precipitated by the addition of chilled acetonitrile (160 $\mu \mathrm{L})$, containing glyburide as an internal standard $(50 \mathrm{ng} / \mathrm{mL})$, and centrifuged at $3000 \mathrm{rpm}$ $\left(4{ }^{\circ} \mathrm{C}\right)$ for $10 \mathrm{~min}$. Resulting supernatants were transferred to new 96-well plates in preparation for LC/MS/MS analysis. The in vitro half-life ( $t_{1 / 2}, \mathrm{~min}$, eq 1$)$, intrinsic 
clearance $\left(\mathrm{CL}_{\mathrm{int}}, \mathrm{mL} / \mathrm{min} / \mathrm{kg}\right.$, eq 2$)$ and subsequent predicted hepatic clearance $\left(\mathrm{CL}_{\mathrm{hep}}\right.$, $\mathrm{mL} / \mathrm{min} / \mathrm{kg}$, eq 3) was determined employing the following equations:

$$
t_{1 / 2}=\ln (2) / k
$$

where $k$ represents the slope from linear regression analysis (\% test article remaining)

$\mathrm{CL}_{\text {int }}=\left(0.693 / t_{1 / 2}\right) \times(\mathrm{rxn}$ volume $/ \mathrm{mg}$ of microsomes $) \times(45 \mathrm{mg}$ of microsomes/gram of $(2)$ liver $) \times\left(20^{a} \mathrm{~g}\right.$ of liver $/ \mathrm{kg}$ body weight $)$

where the superscript $a$ indicates scale-up factors of 20 (human) and 45 (rat) and $Q=$ heptatic blood flow

$$
\mathrm{CL}_{\mathrm{hep}}=\frac{Q \times \mathrm{CL}_{\mathrm{int}}}{Q+\mathrm{CL}_{\mathrm{int}}}
$$

In Vivo-All animal studies were approved by the Vanderbilt University Medical Center Institutional Animal Care and Use Committee. The animal care and use program is fully accredited by the Association for Assessment and Accreditation of Laboratory Animal Care, International.

Male Sprague-Dawley rats $(n=2)$ weighing around $300 \mathrm{~g}$ were purchased from Harlon laboratories (Indianapolis, IN) and implanted with catheters in the carotid artery and jugular vein. The cannulated animals were acclimated to their surroundings for approximately 1 week before dosing and provided food and water ad libitum. IV cassette PK experiments in rats were carried out according to methods described previously (Bridges et al. Pharmacol. Res. Perspect. 2014; reference 49). Briefly, A cassette of compounds ( $n=4-5 /$ cassette) were formulated from $10 \mathrm{mM}$ solutions of compounds in DMSO. In order to reduce the absolute volume of DMSO that was administered, the compounds were combined and diluted with ethanol and PEG400 to achieve a final concentration of $0.4-0.5 \mathrm{mg} / \mathrm{mL}$ for each compound ( $2 \mathrm{mg} / \mathrm{mL}$ total) administered in each cassette. The final dosing solutions consisted of approximately 10\% ethanol, 40\% PEG400, and 50\% DMSO (v/v). Each cassette dose was administered IV via the jugular vein to two dual-cannulated (carotid artery and jugular vein) adult male Sprague-Dawley rats, each weighing between 250 and $350 \mathrm{~g}$ (Harlan, Indianapolis, IN) for a final dose of $0.2-0.25 \mathrm{mg} / \mathrm{kg}$ per compound. Whole blood collections via the carotid artery were performed at $0.033,0.117,0.25,0.5,1,2,4,7$, and $24 \mathrm{~h}$ post dose and plasma samples prepared for bioanalysis. For tissue distribution studies in cassette format, brain dissection and blood collections via the carotid artery were performed at $0.25 \mathrm{~h}$ post dose. Blood samples were collected into chilled, EDTA-fortified tubes, centrifuged for $10 \mathrm{~min}$ at $3000 \mathrm{rpm}\left(4^{\circ} \mathrm{C}\right)$, and resulting plasma aliquoted into 96 -well plates for LC/MS/MS analysis. The brain samples were rinsed in PBS, snap frozen and stored at 
$-80^{\circ} \mathrm{C}$. Prior to LC/MS/MS analysis, brain samples were thawed to room temperature and subjected to mechanical homogenation employing a Mini-Beadbeater and $1.0 \mathrm{~mm}$ Zirconia/ Silica Beads (BioSpec Products). Discrete IV PK experiments in rats $(n=2)$ were carried out analogously at a dose of $1.0 \mathrm{mg} / \mathrm{kg}$ in $10 \% \mathrm{EtOH}, 50 \%$ PEG 400, 40\% saline, while discrete PO PK experiments in rats $(n=2)$ were carried out using a $3 \mathrm{mg} / \mathrm{kg}$ dose of compounds in a fine microsuspension in $30 \%$ Captisol in $\mathrm{H}_{2} \mathrm{O}$ via oral gavage to fasted animals. Whole blood collections via the carotid artery were performed at $0.117,0.25,0.5$, $1,2,4,7$, and $24 \mathrm{~h}$ post dose. Plasma samples were prepared for bioanalysis as described above.

Determination of the pharmacokinetic profile of VU0486846 following a single IV bolus dose of $1 \mathrm{mg} / \mathrm{kg}$ (Ethanol: Peg400: Saline, 10:60:30, v/v/v) and a single PO dose of $3 \mathrm{mg} / \mathrm{kg}$ (30\% aqueous Captisol) to male Cynomolgus monkeys $(n=3)$ was carried out at Frontage Laboratories (Exton, Pennsylvania). Blood was collected at standard PK time points and plasma prepared for bioanalysis as per internal protocols at Frontage. All bioanalysis and calculation of PK parameters was carried out by Frontage and a final report issued upon study completion.

\section{Liquid Chromatography/Mass Spectrometry Analysis}

$M_{1}$ PAMs were analyzed via electrospray ionization (ESI) on an AB Sciex API-4000 (Foster City, CA) triple-quadrupole instrument that was coupled with Shimadzu LC-10AD pumps (Columbia, MD) and a Leap Technologies CTC PAL autosampler (Carrboro, NC). Analytes were separated by gradient elution using a Fortis C18 $2.1 \times 50 \mathrm{~mm}, 3.5 \mu \mathrm{m}$ column (Fortis Technologies Ltd., Cheshire, UK) thermostated at $40{ }^{\circ} \mathrm{C}$. HPLC mobile phase A was $0.1 \%$ formic acid in water ( $\mathrm{pH}$ unadjusted), mobile phase $\mathrm{B}$ was $0.1 \%$ formic acid in acetonitrile (pH unadjusted). The gradient started at $30 \% \mathrm{~B}$ after a 0.2 min hold and was linearly increased to $90 \%$ B over $0.8 \mathrm{~min}$; held at $90 \% \mathrm{~B}$ for $0.5 \mathrm{~min}$ and returned to $30 \% \mathrm{~B}$ in 0.1 min followed by a re-equilibration $(0.9 \mathrm{~min})$. The total run time was $2.5 \mathrm{~min}$ and the HPLC flow rate was $0.5 \mathrm{~mL} / \mathrm{min}$. The source temperature was set at $500{ }^{\circ} \mathrm{C}$ and mass spectral analyses were performed using multiple reaction monitoring (MRM) utilizing a TurboIonspray source in positive ionization mode $(5.0 \mathrm{kV}$ spray voltage). All data were analyzed using AB Sciex Analyst 1.4.2 software. For in vivo studies, the final PK parameters were calculated by noncompartmental analysis using Phoenix (version 6.2) (Pharsight Inc., Mountain View, CA).

\section{Mouse Plasma-Brain Exposure}

$\mathrm{M}_{1}$ PAMs were dissolved in $10 \%$ Tween 80 at the concentration of $1-10 \mathrm{mg} / \mathrm{mL}$ (base form) and administered intraperitoneally to male C57BL/6J (Jackson Laboratory, Sacramento, CA) mice aged 7-9 weeks at a volume of $10 \mathrm{~mL} / \mathrm{kg}$. The blood and brain were collected at 0.25 h. Animals were euthanized and decapitated, and the brains were removed, thoroughly washed with cold saline and immediately frozen on dry ice. Trunk blood was collected in EDTA coated Eppendorf tubes, and plasma was separated by centrifugation and stored at $-80{ }^{\circ} \mathrm{C}$ until processed for LC/MS/MS analysis as previously described. Three animals were used for each time point. 


\section{Electrophysiology Methods}

Animals-All animal studies were approved by the Vanderbilt University Medical Center Institutional Animal Care and Use Committee and were conducted in accordance with the National Institutes of Health Guide for the Care and Use of Laboratory Animals. Male C57BL6/J mice (Jackson laboratories) were used in electrophysiology and behavioral studies (6-10 weeks old). Animals were group housed 4-5 per cage, maintained on a $12 \mathrm{~h}$ light/dark cycle, and provided food and water ad libitum.

Extracellular Field Electrophysiology-Briefly, 6-10 week old male C57BL6/J mice were anesthetized using a mixture of ketamine and xylazine $(100 \mathrm{mg} / \mathrm{kg}$ and $10 \mathrm{mg} / \mathrm{kg}$, respectively, intraperitoneal injection) then transcardially perfused with ice-cold cutting solution (in mM: 230 sucrose, $2.5 \mathrm{KCl}, 8 \mathrm{MgSO}_{4}, 0.5 \mathrm{CaCl}_{2}, 1.25 \mathrm{NaH}_{2} \mathrm{PO}_{4}, 10$ D-glucose, $26 \mathrm{NaHCO}_{3}$ ), and then the brains were removed and submerged in ice-cold cutting solution. Coronal slices containing the prelimbic prefrontal cortex were cut at $400 \mu \mathrm{m}$ using Leica VT1200 vibratome and were transferred to a holding chamber containing NMDG-HEPES recovery solution (in mM: $93 \mathrm{NMDG}, 2.5 \mathrm{KCl}, 1.2 \mathrm{NaH}_{2} \mathrm{PO}_{4}, 30 \mathrm{NaHCO}_{3}, 20$ HEPES, 25 D-glucose, 5 sodium ascorbate, 2 thiourea, 3 sodium pyruvate, $10 \mathrm{MgSO}_{4}, 0.5 \mathrm{CaCl}_{2}, 12 \mathrm{~N}$ acetyl-L-cysteine, $\mathrm{pH} 7.3,<310 \mathrm{mOsm}$ ) for $8-10 \mathrm{~min}$ at $32{ }^{\circ} \mathrm{C}$. Slices were then transferred to a room temperature holding chamber for at least $1.5 \mathrm{~h}$ containing ACSF (in mM: 126 $\mathrm{NaCl}, 1.25 \mathrm{NaH}_{2} \mathrm{PO}_{4}, 2.5 \mathrm{KCl}, 10 \mathrm{D}_{\text {-glucose, }} 26 \mathrm{NaHCO}_{3}, 2 \mathrm{CaCl}_{2}, 1 \mathrm{MgSO}_{4}$ ) supplemented with $600-\mu \mathrm{M}$ sodium ascorbate for slice viability. All buffers were continuously bubbled with $95 \% \mathrm{O} 2 / 5 \% \mathrm{CO}_{2}$. Subsequently, slices were transferred to a 30 $32{ }^{\circ} \mathrm{C}$ submersion recording chamber (Warner Instruments) where they were perfused with ACSF at a rate of $2 \mathrm{~mL} / \mathrm{min}$. Field excitatory postsynaptic potentials (fEPSPs) were recorded from layer $\mathrm{V}$ of the prelimbic cortex and evoked electrically by a concentric bipolar stimulating electrode ( $200 \mu$ s duration, $0.05 \mathrm{~Hz}$; interpulse interval of $50 \mathrm{~ms}$ ) in the superficial layers II-III as described previously (Ghoshal et al., 2017). VU0486846 was diluted to the appropriate concentrations in DMSO ( $<0.1 \%$ final) in ACSF and applied to the bath for 20 min using a peristaltic pump perfusion system. Carbachol and OxoM (Tocris Bioscience, Bristol, UK) were diluted in $\mathrm{H}_{2} \mathrm{O}$. See the Supporting Information for additional information.

Stereotaxic Viral Injections-Mice underwent stereotaxic injections for viral-mediated gene transfer of channelrhodopsin-2 (ChR2) at 4-5 weeks of age. Mice were anaesthetized with 1-2\% isoflurane for the duration of the surgery and were administered carprofen (10 $\mathrm{mg} / \mathrm{kg}$, s.c.) before the surgery commenced. Following a craniotomy, one injection per hemisphere $(800 \mathrm{~nL}$ at a rate of $100 \mathrm{~nL} / \mathrm{min}$ ) of AAV5-CaMKII-ChR2-EYFP (UNC Viral Vector Core) was delivered into the target regions through a $28 \mathrm{G}$ needle attached to a $10 \mu \mathrm{L}$ Hamilton syringe. Injection site coordinates were as follows (relative to bregma): vHipp [ML: \pm 3.4 , AP: -3.4 , DV: -4.0 ]. Carprofen $(10 \mathrm{mg} / \mathrm{kg}$, s.c. $)$ was administered for at least 72 $\mathrm{h}$ post procedure. Recordings were made $4-5$ weeks following surgery to allow sufficient expression of ChR2 in axon terminals within the PFC.

Optical Extracellular Field Electrophysiology-Brain slices from viral injected mice were prepared in a similar manner described above. For studies involving optical 
stimulation, blue light $(470 \mathrm{~nm}$ ) was delivered using a High-Power LED (Thorlabs Inc. Newton, NJ), which was mounted to the epi-illumination port of an Olympus BX50WI upright microscope (Olympus). Blue light was shined onto slices through the $40 \times$ objective lens at $0.05 \mathrm{~Hz}$ (Maximum light intensity at the site of illumination is $2.6 \mathrm{~mW}$ ).

\section{Behavioral Pharmacology Studies}

Animals-In vivo studies utilized either 7-8 week old male C57B1/6 mice (Jackson Laboratory, Sacramento, CA) or male Sprague-Dawley rats weighing 275-300 g (Envigo, Indianapolis, IN). The animals were cared for in accordance with the National Institutes of Health Guide for the Care and Use of Laboratory Animals. All experimental procedures were approved by the Vanderbilt University Animal Care and Use Committee.

Novel Object Recognition Task-Novel object recognition memory was assessed as previously described. ${ }^{26}$ Briefly, rats were habituated to an empty novel object recognition (NOR) arena. On test day, rats were administered vehicle (10\% tween 80) or VU0486846 (1-10 mg/kg, intraperitoneally (i.p.), $1 \mathrm{~mL} / \mathrm{kg}, n=12$ ) and returned to their home cage for $30 \mathrm{~min}$. Rats were then placed in the NOR arena containing 2 identical objects for $10 \mathrm{~min}$. Following the exposure period, rats were placed back into their home cages for $24 \mathrm{~h}$. The rats were then returned to the arena in which one of the previously exposed (familiar) objects was replaced by a novel object and exploration behavior was assessed for $3 \mathrm{~min}$. Time spent exploring each object was scored by an observer blinded to the experimental conditions and the recognition index was calculated as [(time spent exploring novel object) - (time spent exploring familiar object)]/total time exploring objects.

Contextual Fear Conditioning-The effects of VU0486846 on acquisition of contextual fear conditioning were evaluated in rats as previously described. ${ }^{42}$ Rats were given a $30 \mathrm{~min}$ pretreatment of vehicle (10\% Tween 80$)$, risperidone alone $(3 \mathrm{mg} / \mathrm{kg}$, i.p., $1 \mathrm{~mL} / \mathrm{kg})$, or risperidone coadministered with VU0486846 $(1-10 \mathrm{mg} / \mathrm{kg})$ and placed in a soundattenuating conditioning chamber (Med Associates). Following a 2 min habituation period, rats received three shock-tone pairing trials $(30 \mathrm{~s} 3000 \mathrm{~Hz} 80 \mathrm{~dB}$ tone coterminated with a 1 $\mathrm{s}, 0.5 \mathrm{~mA}$ shock) in the presence of a $10 \%$ vanilla solution scent and then returned to their home cages. Twenty four hours later, acquisition of fear conditioning was assessed in the same conditioning environment for $4 \mathrm{~min}$ by measuring freezing behavior in the absence of any shock stimuli or drug. Testing sessions were recorded and time spent freezing was automatically scored using video freeze software (MED-VFC-RS, MedAssociates).

Modified Irwin Toxicology Battery-The potential CNS adverse effects of VU0486846 were evaluated using the Modified Irwin Toxicology Battery. Baseline assessments were conducted prior to administration of compounds. Mice were administered vehicle or VU0486846 (100 mg/kg, $10 \%$ Tween $80,10 \mathrm{~mL} / \mathrm{kg}$, i.p., $n=3)$ while rats were administered vehicle or VU0486846 (56.6 mg/kg, 10\% Tween 80, $2 \mathrm{~mL} / \mathrm{kg}$, i.p., $n=3)$. Animals were then placed back into their home cages and evaluated by an observer blinded to dosing conditions at 15,30,60,180, and $360 \mathrm{~min}$ for autonomic nervous and somatomotor system parameters. Animals were assigned a score for each parameter of 0 (normal), 1 (slight/light), 2 (moderate), or 3 (marked) relative to vehicle-treated controls. 


\section{Supplementary Material}

Refer to Web version on PubMed Central for supplementary material.

\section{Acknowledgments}

Funding

This work was funded by the NIH and NIMH (MH082867 and MH106839).

We thank William K. Warren, Jr. and the William K. Warren Foundation who funded the William K. Warren, Jr. Chair in Medicine (to C.W.L.).

\section{ABBREVIATIONS}

$\begin{array}{ll}\text { ACh } & \text { acetylcholine } \\ \text { i.p } & \text { intraperioneal } \\ \text { p.o } & \text { oral dosing } \\ \text { LTS } & \text { GPCR, G protein-coupled receptor } \\ \text { M1 } & \text { muscarinic acetylcholine receptor subtype 1 } \\ \text { NOR } & \text { novel object recognition } \\ \text { CFC } & \text { contextual fear conditioning }\end{array}$

\section{References}

1. Melancon BJ, Tarr JC, Panarese JD, Wood MR, Lindsley CW. Allosteric modulation of the $\mathrm{M}_{1}$ muscarinic acetylcholine receptor: improving cognition and a potential treatment for schizophrenia and Alzheimer's disease. Drug Discovery Today. 2013; 18:1185-1199. [PubMed: 24051397]

2. Bridges TM, LeBois EP, Hopkins CR, Wood MR, Jones JK, Conn PJ, Lindsley CW. Antipsychotic potential of muscarinic allosteric modulation. Drug News Perspect. 2010; 23:229-240. [PubMed: 20520852]

3. Levey AI, Kitt CA, Simonds WF, Price DL, Brann MR. Identification and localization of muscarinic acetylcholine receptor proteins in brain with subtype-specific antibodies. J Neurosci. 1991; 11:3218-3226. [PubMed: 1941081]

4. Levey AI, Edmunds SM, Koliatsos V, Wiley RG, Heilman CJ. Expression of M1-M4 muscarinic acetylcholine receptor proteins in rat hippocampus and regulation by cholinergic innervations. J Neurosci. 1995; 15:4077-4092. [PubMed: 7751967]

5. Levey AI. Muscarinic acetylcholine receptor expression in memory circuits: implications for treatment of Alzheimer disease. Proc Natl Acad Sci U S A. 1996; 93:13541-13546. [PubMed: 8942969]

6. Felder CC, Porter AC, Skillman TL, Zhang L, Bymaster FP, Nathanson NM, Hamilton SE, Gomeza J, Wess J, McKinzie DL. Elucidating the role of muscarinic receptors in psychosis. Life Sci. 2001; 68:2605-2613. [PubMed: 11392633]

7. Anagnostaras SG, Murphy GG, Hamilton SE, Mitchell SL, Rahnama NP, Nathanson NM, Silva AJ. Selective cognitive dysfunction in acetylcholine M1 muscarinic receptor in mutant mice. Nat Neurosci. 2003; 6:51-58. [PubMed: 12483218]

8. Caccamo A, Oddo S, Billings LM, Green KN, MartinezCoria H, Fisher A, LaFerla FM. M1 receptors play a central role in modulating AD-like pathology in transgenic mice. Neuron. 2006; 49:671-682. [PubMed: 16504943] 
9. Caccamo A, Fisher A, LaFerla FM. M1agonists as a potential disease-modifying therapy for Alzheimer's disease. Curr Alzheimer Res. 2009; 6:112-117. [PubMed: 19355845]

10. Dean B, Hopper S, Conn PJ, Scarr E. Changes in BQCA allosteric modulation of $\left[{ }^{3} \mathrm{H}\right]-\mathrm{NMS}$ binding to human cortex within schizophrenia and by divalent cations. Neuropsychopharmacology. 2016; 41:1620-1628. [PubMed: 26511338]

11. Scarr E, Udawela M, Thomas EA, Dean B. Changed gene expression in subjects with schizophrenia and low cortical muscarinic M1 receptors predict disrupted upstream pathways interacting with that receptor. Mol Psychiatry. 2018; 23:295-303. [PubMed: 27801890]

12. Conn PJ, Lindsley CW, Meiler J, Niswender CM. Opportunities and challenges in the discovery of allosteric modulators of GPCRs for the treatment of CNS disorders. Nat Rev Drug Discovery. 2014; 13:692-708. [PubMed: 25176435]

13. Melancon BJ, Hopkins CR, Wood MR, Emmitte KA, Niswender CM, Christopoulos A, Conn PJ, Lindsley CW. Allosteric Modulation of 7 Transmembrane Spanning Receptors: Theory, Practice and Opportunities for CNS Drug Discovery. J Med Chem. 2012; 55:1445-1464. [PubMed: 22148748]

14. Menniti FS, Lindsley CW, Conn PJ, Pandit J, Zagouras P, Volkmann RA. Allosteric modulation for the treatment of schizophrenia: Targeting glutamatergic networks. Curr Top Med Chem. 2013; 13:26-54. [PubMed: 23409764]

15. Raedler TJ, Bymaster FP, Tandon R, Copolov D, Dean B. Towards a Muscarinic Hypothesis of Schizophrenia. Mol Psychiatry. 2007; 12:232-246. [PubMed: 17146471]

16. Bender AM, Jones CK, Lindsley CW. Classics in Chemical Neuroscience: Xanomeline. ACS Chem Neurosci. 2017; 8:435-443. [PubMed: 28141924]

17. Dencker D, Thomsen M, Wörtwein G, Weikop P, Cui Y, Jeon J, Wess J, Fink-Jensen A. Muscarinic Acetylcholine Receptor Subtypes as Potential Drug Targets for the Treatment of Schizophrenia, Drug Abuse, and Parkinson's Disease. ACS Chem Neurosci. 2012; 3:80-89. [PubMed: 22389751]

18. Kruse AC, Kobilka BK, Gautam D, Sexton PM, Christopoulos A, Wess J. Muscarinic Acetylcholine Receptors: Novel Opportunities for Drug Development. Nat Rev Drug Discovery. 2014; 13:549-560. [PubMed: 24903776]

19. Ma L, Seager M, Wittman M, Bickel N, Burno M, Jones K, Graufelds VK, Xu G, Pearson M, McCampbell A, Gaspar R, Shughrue P, Danzinger A, Regan C, Garson S, Doran S, Kreatsoulas C, Veng L, Lindsley CW, Shipe W, Kuduk S, Jacobson M, Sur C, Kinney G, Seabrook GR, Ray WJ. Selective activation of the M1 muscarinic acetylcholine receptor achieved by allosteric potentiation. Proc Natl Acad Sci U S A. 2009; 106:15950-15955. [PubMed: 19717450]

20. Shirey JK, Brady AE, Jones PJ, Davis AA, Bridges TM, Jadhav SB, Menon U, Christain EP, Doherty JJ, Quirk MC, Snyder DH, Levey AI, Watson ML, Nicolle MM, Lindsley CW, Conn PJ. A selective allosteric potentiator of the $\mathrm{M}_{1}$ muscarinic acetylcholine receptor increases activity of medial prefrontal cortical neurons and can restore impairments of reversal learning. J Neurosci. 2009; 29:14271-14286. [PubMed: 19906975]

21. Yang FV, Shipe WD, Bunda JL, Nolt MB, Wisnoski DD, Zhao Z, Barrow JC, Ray WJ, Ma L, Wittman M, Seager M, Koeplinger K, Hartman GD, Lindsley CW. Parallel synthesis of $N$-Birayl Quinolone Carboxylic Acids as selective $\mathrm{M}_{1}$ positive allosteric modulators. Bioorg Med Chem Lett. 2010; 20:531-536. [PubMed: 20004574]

22. Uslaner JM, Kuduk SD, Wittmann M, Lange HS, Fox SV, Min C, Pajkovic N, Harris D, Cilissen C, Mahon C, Mostoller K, Warrington S, Beshore DC. Preclinical to Human Translational Pharmacology of the Novel $\mathrm{M}_{1}$ Positive Allosteric Modulator MK-7622. J Pharmacol Exp Ther. 2018 jpet.117.245894.

23. Moran SP, Dickerson JW, Plumley HC, Xiang Z, Maksymetz J, Remke DH, Doyle CA, Niswender CM, Engers DW, Lindsley CW, Rook JM, Conn PJ. M 1 positive allosteric modulators lacking agonist activity provide the optimal profile for enhancing cognition. Neuropsychopharmacology. 2018; doi: 10.1038/s41386-018-0033-9

24. Bridges TM, Kennedy JP, Cho HP, Conn PJ, Lindsley CW. Chemical optimization of an $\mathrm{M}_{1}, \mathrm{M}_{3}$, $\mathrm{M}_{5}$ positive allosteric modulator (PAM) lead. Part II Development of a highly selective $\mathrm{M}_{1}$ PAM. Bioorg Med Chem Lett. 2010; 20:1972-1975. [PubMed: 20156687] 
25. Ghoshal A, Rook J, Dickerson J, Roop G, Morrison R, Jalan-Sakrikar N, Lamsal A, Noetzel M, Poslusney M, Stauffer SR, Xiang Z, Daniels JS, Niswender CM, Jones CK, Lindsley CW, Conn PJ. Selective potentiation of $M_{1}$ muscarinic receptors reverses deficits in plasticity and negative and cognitive symptoms in repeated phencyclidine treated mouse model of schizophrenia. Neuropsychopharmacology. 2016; 41:598-610. [PubMed: 26108886]

26. Grannan MD, Mielnik CA, Moran SP, Gould RW, Ball J, Bubser M, Ramsey AJ, Abe M, Cho HP, Nance KD, Blobaum AL, Niswender CM, Conn PJ, Lindsley CW, Jones CK. Prefrontal cortexmediated impairments in a genetic model of NMDA receptor hypofunction are reversed by the novel M 1 PAM VU6004256. ACS Chem Neurosci. 2016; 7:1706-1716. [PubMed: 27617634]

27. Rook JM, Abe M, Cho HP, Nance KD, Luscombe VB, Adams JJ, Dickerson JW, Remke DH, Garcia-Barrantes PM, Engers DW, Engers JL, Chang S, Foster JJ, Blobaum AL, Niswender CM, Jones CK, Conn PJ, Lindsley CW. Diverse Effects on $\mathrm{M}_{1}$ Signaling and Adverse Effect Liability within a Series of $\mathrm{M}_{1}$ Ago-PAMs. ACS Chem Neurosci. 2017; 8:866-883. [PubMed: 28001356]

28. Davoren JE, O’Neil SV, Anderson DP, Brodeny MA, Chenard L, Dlugolenski K, Edgerton JR, Green M, Garnsey M, Grimwood S, Harris AR, Kauffman GW, LaChapelle E, Lazzaro JT, Lee CW, Lotarski SM, Nason DM, Obach RS, Reinhart V, Salomon-Ferrer R, Steyn SJ, Webb D, Yan J, Zhang L. Design and optimization of selective azaindole amides M1 positive allosteric modulators. Bioorg Med Chem Lett. 2016; 26:650-655. [PubMed: 26631313]

29. Davoren JE, Lee CW, Garnsey M, Brodney MA, Cordes J, Dlugolenski K, Edgerton JR, Harris AR, Helal CJ, Jenkinson S, Kauffman GW, Kenakin TP, Lazzaro JT, Lotarski SM, Mao Y, Nason DM, Northcott C, Nottebaum L, O’Neil SV, Pettersen B, Popiolek M, Reinhart V, Salomon-Ferrer R, Steyn SJ, Webb D, Zhang L, Grimwood S. Discovery of the Potent and Selective M1 PAMAgonist $N$-[(3R,4S)-3-Hydroxytetrahydro-2H-pyran-4-yl]-5-methyl-4-[4-(1,3-thiazol-4yl)benzyl]pyridine-2-carboxamide (PF-06767832): Evaluation of Efficacy and Cholinergic Side Effects. J Med Chem. 2016; 59:6313-6328. [PubMed: 27275946]

30. Moran SP, Cho HP, Maksymetz J, Remke D, Hanson R, Niswender CM, Lindsley CW, Rook JM, Conn PJ. PF-06827443 displays robust allosteric agonist and positive allosteric modulator activity in high receptor reserve and native systems. ACS Chem Neurosci. 2018; doi: 10.1021/ acschemneuro.8b00106

31. Yang ZQ, Shu Y, Ma L, Wittmann M, Ray WJ, Seager MA, Koeplinger KA, Thompson CD, Hartman GD, Bilodeau MT, Kuduk SD. Discovery of naphthyl-fused 5-membered lactams as a new class of M1 positive allosteric modulators. ACS Med Chem Lett. 2014; 5:604-608. [PubMed: 24900888]

32. See the Supporting Information for full details.

33. Wager TT, Hou X, Verhoest PR, Villalobos A. Central Nervous System Multiparameter Optimization Desirability: Application in Drug Discovery. ACS Chem Neurosci. 2016; 7:767-775. [PubMed: 26991242]

34. Vardigan JD, Cannon CE, Puri V, Dancho M, Koser A, Wittmann M, Kuduk SD, Renger JJ, Uslaner JM. Improved cognition without adverse effects: novel M1 potentiatir compares favorably to donepezil and xanomeline in rhesus monkey. Psychopharmacology. 2015; 232:1859-1866. [PubMed: 25491927]

35. Lange HS, Cannon CE, Drott JT, Kuduk SD, Uslaner JM. The M1Muscarinic Positive Allosteric Modulator PQCA Improves Performance on Translatable Tests of Memory and Attention in Rhesus Monkeys. J Pharmacol Exp Ther. 2015; 355:442-450. [PubMed: 26446308]

36. Ghoshal A, Conn PJ. The hippocampal-prefrontal pathway: a possible therapeutic target for the negative and cognitive symptoms of schizophrenia. Future Neurol. 2015; 10:115-128. [PubMed: 25825588]

37. Sigurdsson T, Duvarci S. Hippocampal-prefrontal interactions in cognition, behavior and psychiatric disease. Front Syst Neurosci. 2016; 9:190. [PubMed: 26858612]

38. Hill SK, Bishop JR, Palumbo D, Sweeney JA. Effects of second generation antipsychotics on cognition: current issues and future challenges. Expert Rev Neurother. 2010; 10:43-57. [PubMed: 20021320]

39. Keefe RS, Bilder RM, Davis SM, Harvey PD, Palmer BW, Gold JM, Meltzer HY, Green MF, Capuano G, Stroup TS, McEvoy JP, Swartz MS, Rosenheck RA, Perkins DO, Davis CE, Hsiao JK, Lieberman JA. CATIE Investigators, Neurocognitive Working Group. Neurocognitive effects of 
antipsychotic medications in patients with chronic schizophrenia in the CATIE Trial. Arch Gen Psychiatry. 2007; 64:633-647. [PubMed: 17548746]

40. Nishiyama K, Sugishita M, Kurisaki H, Sakuta M. Reversible memory disturbance and intelligence impairment induced by long-term anticholinergic therapy. Intern Med. 1998; 37:514-518. [PubMed: 9678684]

41. Castner SA, Williams GV, Goldman-Rakic PS. Reversal of Antipsychotic Induced Working Memory Deficits by Short-Term Dopamine D1 Receptor Stimulation. Science. 2000; 287:2020 2022. [PubMed: 10720329]

42. Rook JM, Xiang Z, Lv X, Ghosal A, Dickerson J, Bridges TM, Johnson KA, Bubser M, Gregory KJ, Vinson PN, Byun N, Stauffer SR, Daniels JS, Niswender CM, Lavreysen H, Mackie C, CondeCeide S, Alcazar J, Bartolome JM, Macdondald GJ, Steckler T, Jones CK, Lindsley CW, Conn PJ. Biased $\mathrm{mGlu}_{5}$ positive allosteric modulators provide in vivo efficacy without potentiating $\mathrm{mGlu}_{5}$ modulation of NMDAR currents. Neuron. 2015; 86:1029-1040. [PubMed: 25937172] 
<smiles>COc1ccc(Cn2cc(C(=O)O)c(=O)c3ccccc32)cc1</smiles>

BQCA (1)<smiles>Cn1cc(-c2ccc(Cn3cc(C(=O)N[C@H]4CCCC[C@H]4O)c4c(F)cc(F)cc43)cn2)cn1</smiles>

VU6004256 (4)<smiles>Cc1ccc(Cc2cc3c(=O)n([C@@H]4CCCC[C@H]4O)cnc3c3ccccc23)cn1</smiles>

MK-7622 (2)<smiles>Cn1ccc(-c2ccc(Cn3cc(C(=O)N[C@H]4CCOC[C@H]4O)c4ncccc43)cc2)n1</smiles>

PF-06764427 (5)<smiles>Cn1cc(-c2ccc(CN3Cc4ncccc4C3=O)c(F)c2)cn1</smiles>

VU0453595 (3)<smiles>Cc1cc2c(cc1Cc1ccc(-c3cocn3)cc1)C(=O)N([C@@H]1CCOC[C@H]1O)C2</smiles>

PF-06827443 (6)

Figure 1.

Structures of reported $M_{1}$ PAMs with varying degrees of $M_{1}$ PAM potency, varying degrees of $\mathrm{M}_{1}$ ago-PAM activity in recombinant cell lines and native tissues, and a diverse range of cholinergic AEs. 


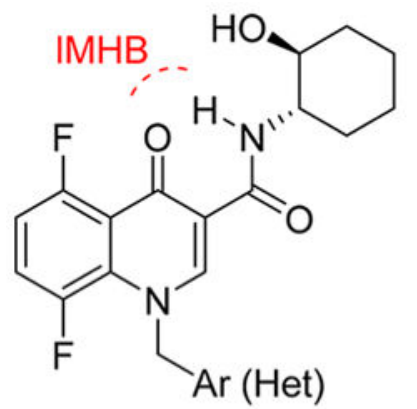

7 from quinolone to benzomorpholine

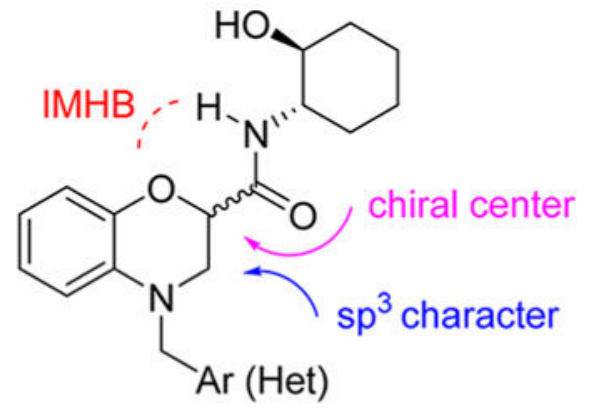

8

Figure 2.

Ligand design concept to scaffold hop from the classical $\mathrm{M}_{1}$ PAM quinolone core of $\mathbf{1}$ and $\mathbf{7}$ to a novel, benzomorphoine core $\mathbf{8}$, bearing a new chiral center and increased $\mathrm{sp}^{3}$ character. 

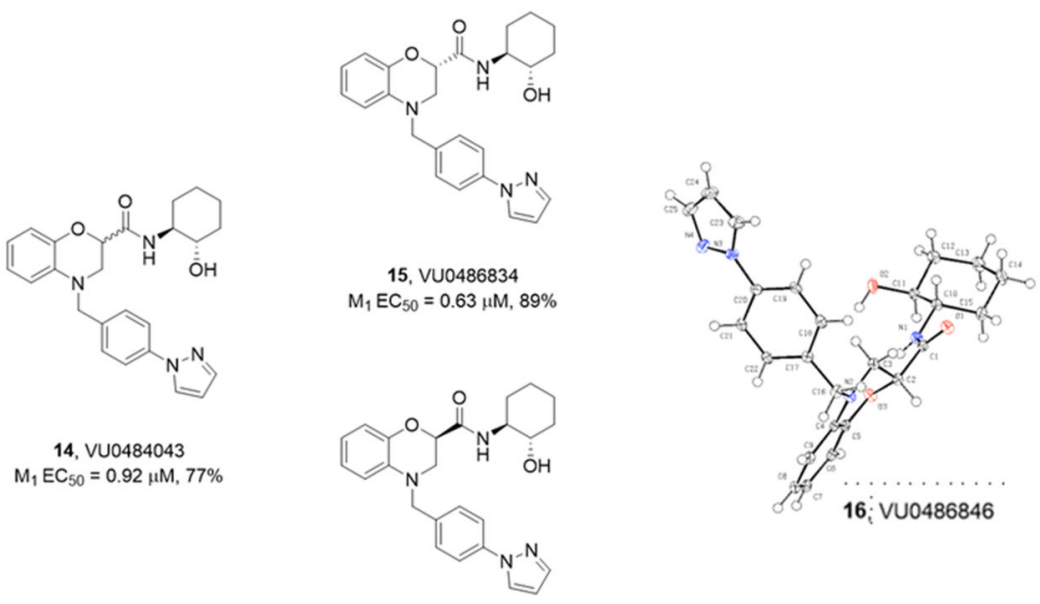

16. VU0486846 $\mathrm{M}_{1} \mathrm{EC}_{50}=0.31 \mu \mathrm{M}, 85 \%$

Figure 3.

Structures and human $\mathrm{M}_{1}$ PAM activities of 14-16, as well as a single X-ray crystal structure of the more active $(R)$-enantiomer 16 (VU0486846). 
A

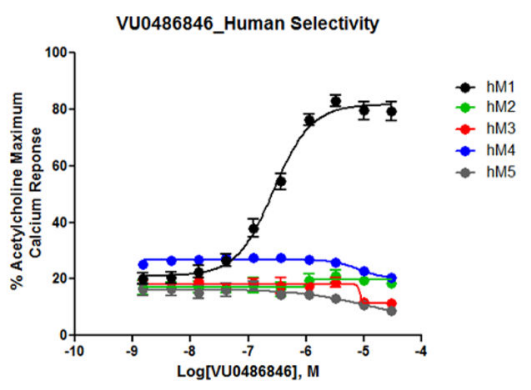

B

Vu0486846_Rat Selectivity

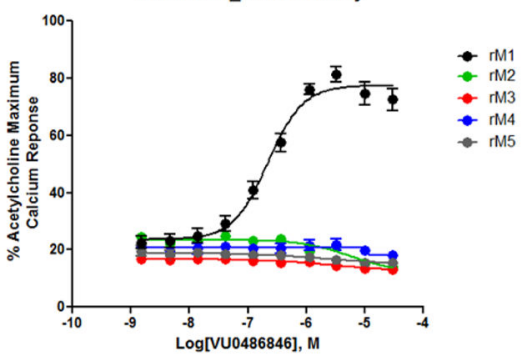

C

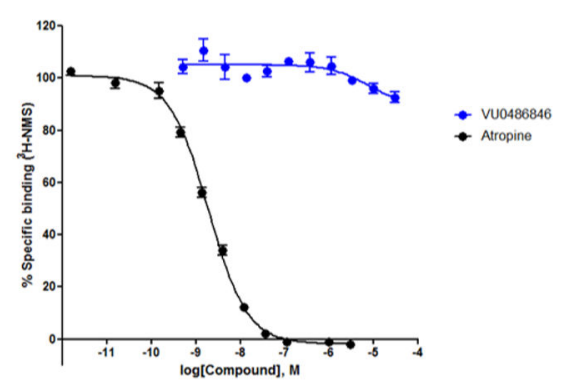

Figure 4.

Molecular pharmacology profile of 16. (A) Human $\mathrm{M}_{1} \mathrm{CRC}\left(\mathrm{EC}_{50}=308 \mathrm{nM}\right)$ versus $\mathrm{M}_{2}-$ $\mathrm{M}_{5}$ (inactive). (B) Rat $\mathrm{M}_{1} \mathrm{CRC}\left(\mathrm{EC}_{50}=253 \mathrm{nM}\right)$ versus $\mathrm{M}_{2}-\mathrm{M}_{5}$ (inactive). (C) Inhibition of orthosteric radioligand binding with $\left[{ }^{3} \mathrm{H}\right]-\mathrm{NMS}$ by VU0486846 and atropine control. VU0486846 does not substantially inhibit binding of $\left[{ }^{3} \mathrm{H}\right]-\mathrm{NMS}$ up to $30 \mu \mathrm{M}$. 

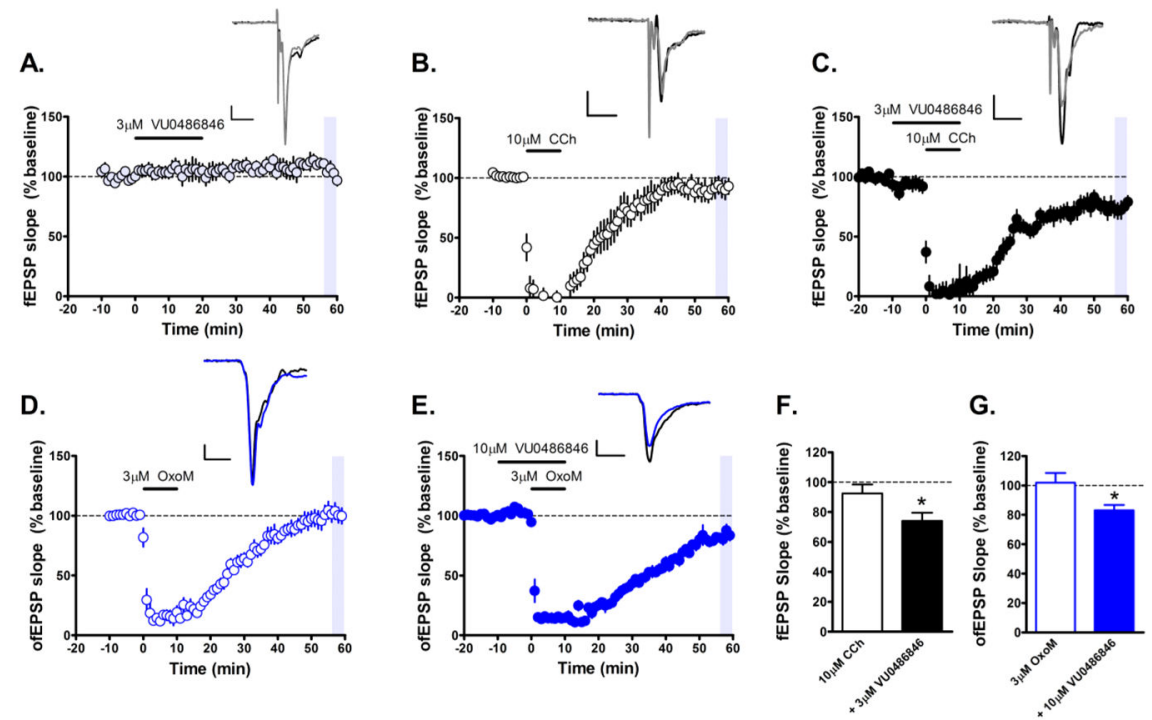

Figure 5.

$M_{1}$ PAM VU0486846 can robustly potentiate a submaximal cholinergic agonist-induced long-term depression (LTD) in layer $\mathrm{V}$ of the prelimbic mPFC evoked by either electrical or optical stimulation. (A) Time course graph showing that bath application of $3 \mu \mathrm{M}$

VU0486846 for 20 min led to no significant change in fEPSP slope. (B) Time course graph showing that bath application of $10 \mu \mathrm{M}$ carbachol $(\mathrm{CCh})$, a cholinergic agonist, induces a negligible LTD of fEPSPs in layer V electrically evoked by stimulation of layer II/III in the mPFC. (C) 10 min pretreatment of the $\mathrm{M}_{1}$ PAM VU0486846 (3 $\left.\mu \mathrm{M}\right)$ followed by a $10 \mathrm{~min}$ coapplication of PAM and $10 \mu \mathrm{M}$ CCh led to a robust LTD of electrically evoked fEPSP slope. Inset shows representative fEPSP traces for each condition for baseline (black trace) and 50 min after CCh washout (gray trace). (D) Time course graph showing that bath application of $3 \mu \mathrm{M}$ OxoM, a selective muscarinic agonist, for $10 \mathrm{~min}$ led to an acute depression followed by a minimal LTD of optically evoked fEPSPs (ofEPSP) measured 46$50 \mathrm{~min}$ following drug washout. (E) Under similar conditions, bath application $10 \mathrm{~min}$ pretreatment of the $\mathrm{M}_{1}$ PAM VU0486846 $(10 \mu \mathrm{M})$ followed by a 10 min coapplication of PAM with $3 \mu \mathrm{M}$ OxoM led to a robust LTD of ofEPSP slope. Inset shows representative ofEPSP traces for each condition for baseline (black trace) and $50 \mathrm{~min}$ after OxoM washout (blue trace). (F) Quantification of fEPSP slope 46-50 min following drug washout (shaded area) indicates a significant depression of fEPSP slope with $3 \mu \mathrm{M}$ VU0486846 $+10 \mu \mathrm{M} \mathrm{CCh}$ compared to $10 \mu \mathrm{M} \mathrm{CCh}$ alone ( $n=9$ brain slice experiments per group). (G) Quantification of ofEPSP slope 46-50 min following drug washout (shaded area) indicates a significant depression of ofEPSP with $10 \mu \mathrm{M}$ VU0486846 $+3 \mu \mathrm{M}$ OxoM compared to $3 \mu \mathrm{M}$ OxoM alone ( $n=6-8$ brain slice experiments per group). Scale bars denote $0.5 \mathrm{mV}$ and $5 \mathrm{~ms}$. Data are expressed as mean $\pm \mathrm{SEM} ; * p<0.05$, Student's $t$ test. 


\section{A Novel Object Recognition}

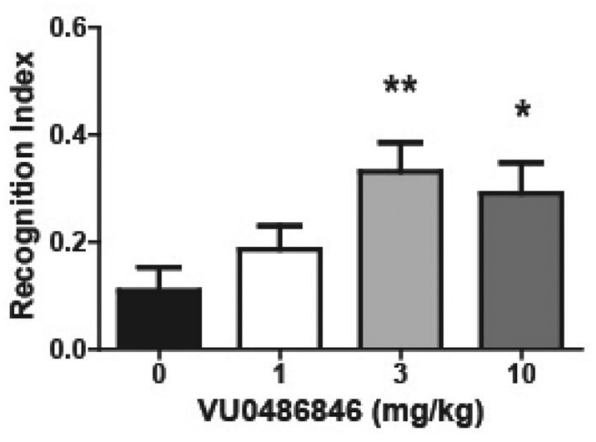

B Fear Conditioning

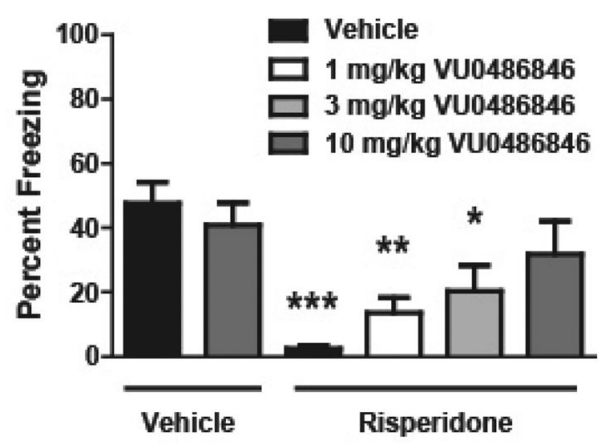

Figure 6.

Novel object recognition and contextual fear conditioning. (A) VU0486846 dosedependently enhanced recognition memory in rats. Pretreatment with 3 and $10 \mathrm{mg} / \mathrm{kg}$ VU0486846 (i.p., 10\% Tween 80 in water, $30 \mathrm{~min}$ ) prior to exposure to identical objects significantly enhanced recognition memory assessed $24 \mathrm{~h}$ later. (B) VU0486846 dosedependently reversed risperidone-induced deficits in acquisition of contextual fear conditioning. When coadministered with $3 \mathrm{mg} / \mathrm{kg}$ risperidone, $10 \mathrm{mg} / \mathrm{kg} \mathrm{VU0486846}$ restored conditioned freezing to vehicle-treated control levels. Data are expressed as mean \pm SEM ( $n=11-13)$. Statistical analysis was conducted using a one-way analysis of variance. If significant $(p<0.05)$, comparison of group effects relative to the vehicle group was completed using a Dunnett's test, $* p<0.05, * * p<0.01, * * * p<0.001$. 


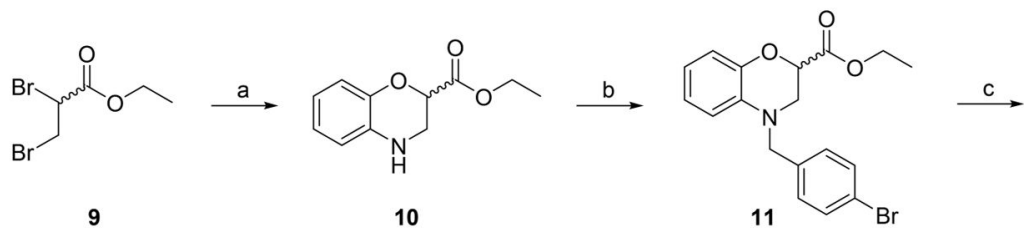

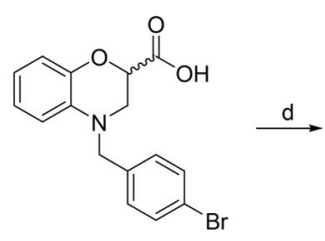

12

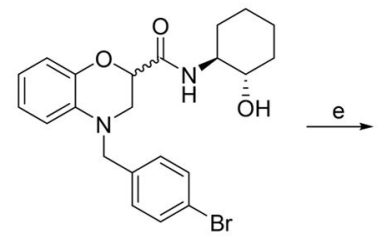

13

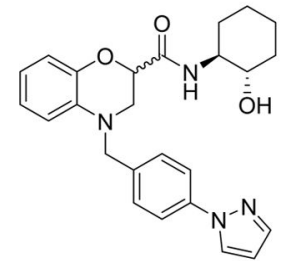

14

Scheme 1.

Synthesis of Benzomorpholine-Based $\mathrm{M}_{1}$ PAM $14^{a}$

${ }^{a}$ Reagents and conditions: (a) 2-aminophenol, $\mathrm{CH}_{3} \mathrm{CN}, \mathrm{K}_{2} \mathrm{CO}_{3}, 80{ }^{\circ} \mathrm{C}, 65 \%$; (b) 4 bromobenzyl bromide, $\mathrm{K}_{2} \mathrm{CO}_{3}, \mathrm{CH}_{3} \mathrm{CN}, 80^{\circ} \mathrm{C}, 74 \%$; (c) $\mathrm{KOH}, \mathrm{THF} / \mathrm{H}_{2} \mathrm{O}$ (2:1), rt, $98 \%$; (d) $(1 S, 2 S)$-2-aminocyclohexan-1-ol, HATU, DIEA, DMF, rt, 80\%; (e) pyrazole, $(1 S, 2 S)$ $N^{1}, N^{2}$-dimethylcyclohexane-1,2- diamine, CuI, $\mathrm{K}_{3} \mathrm{PO}_{4}$, dioxane, $100{ }^{\circ} \mathrm{C}, 65 \%$. 